\title{
Testing the Impact of Braking Algorithm Parameters on Acceleration and Braking Distance for a Suspended Monorail with Regard to Acceptable Travel Speed in Hard Coal Mines
}

\author{
Jerzy Świder ${ }^{1}$, Kamil Szewerda ${ }^{2, *} \mathbb{C}$, Krzysztof Herbus $^{1}{ }^{\mathbb{D}}$ and Jerzy Jura ${ }^{2}$ \\ 1 Department of Engineering Processes Automation and Integrated Manufacturing Systems, \\ Faculty of Mechanical Engineering, Silesian University of Technology, 44-100 Gliwice, Poland; \\ jerzy.swider@polsl.pl (J.Ś.); krzysztof.herbus@polsl.pl (K.H.) \\ 2 KOMAG Institute of Mining Technology, 44-101 Gliwice, Poland; jjura@komag.eu \\ * Correspondence: kszewerda@komag.eu
}

Citation: Świder, J.; Szewerda, K.; Herbuś, K.; Jura, J. Testing the Impact of Braking Algorithm Parameters on Acceleration and Braking Distance for a Suspended Monorail with Regard to Acceptable Travel Speed in Hard Coal Mines. Energies 2021, 14, 7275. https://doi.org/10.3390/en14217275

Academic Editor: Maxim Tyulenev

Received: 15 October 2021

Accepted: 29 October 2021

Published: 3 November 2021

Publisher's Note: MDPI stays neutral with regard to jurisdictional claims in published maps and institutional affiliations.

Copyright: (c) 2021 by the authors Licensee MDPI, Basel, Switzerland. This article is an open access article distributed under the terms and conditions of the Creative Commons Attribution (CC BY) license (https:/ / creativecommons.org/licenses/by/ $4.0 /)$.

\begin{abstract}
Increasing the maximum speed limit of suspended monorails, which became a very popular means of auxiliary transport, is one of the aspects of improving the efficiency of work in underground coal mines. It is especially important to enable higher (than allowed by the law) travel speed, when moving the crew to and from the workplace, which is often very distant from the shaft, and can take more than one hour of travel. Increasing this speed will make it possible to extend the effective working time of miners, which should have a positive impact on the economics of the mine. However, driving at a higher speed is also associated with increased risk of a negative impact of dynamic overload to people, e.g., during emergency braking of the suspended monorail. The concept of sequential emergency braking was developed in order to avoid excessive deceleration affecting passengers and the operator of the monorail, as well as to minimize the dynamic loads acting on the rail suspensions and on the roadway support frames, which could cause serious accidents. The developed assumptions with regard to the new method of braking are innovative in the area related to hard coal mining, where there are currently no such solutions. According to the principles of the developed concept, the total braking force was divided into two stages. The activation of the second stage depends on the deceleration measured after the time delay from activation of the first stage of braking. We present the results of the numerical simulations, which aimed to analyze the impact of changing the parameters of the braking algorithm on the braking deceleration, the braking time, and the braking distance. The possibility of changing the braking force and downward emergency braking on a high inclination angle were also taken into account during the numerical simulations. Use of the developed emergency braking algorithm enables the optimization of this process at a higher speed than is currently used. This aspect is also very important in increasing the safety for people travelling at a higher speed limit. The numerical simulations provide knowledge for safety in terms of the dynamic overload during emergency braking, without injury risk to miners or damage to equipment.
\end{abstract}

Keywords: mining industry; numerical simulations; suspended monorails; travel speed; braking algorithm

\section{Introduction}

The improvement of auxiliary transport efficiency is an important aspect of increasing labor productivity in underground coal mines. Suspended monorails, used for the transportation of materials and the movement of miners to and from the mining face area, are the main transportation means. Increase in the distance to mining panels from the shafts extends the time necessary to cover this distance, with a set speed limit, within which the suspended monorail can move. The speed limit for transportation is defined by the national regulations of each country. In Poland, the maximum speed of people 
movement is $2 \mathrm{~m} / \mathrm{s}$, while the brakes operate automatically after exceeding the permissible speed by $50 \%$, but not more than by $1 \mathrm{~m} / \mathrm{s}$ [1]. This provision in the Polish regulations enables setting the trigger of the emergency braking trolley to $3 \mathrm{~m} / \mathrm{s}$. A similar limit for the permissible speed of a suspended monorail was adopted in Slovenia. In turn, in Germany, the maximum permissible speed is $3 \mathrm{~m} / \mathrm{s}$. In accordance with regulations in Ukraine, the speed of transportation is determined on the basis of the railway's technical and operational documentation and the manufacturer's specifications, and the maximum permissible speed, equal to $1 \mathrm{~m} / \mathrm{s}$, applies to transportation of long and large-size loads. In the case of countries outside the European Union, Polish producers usually apply Polish regulations regarding the admission of suspended monorails to traffic, which are accepted in countries such as China, Mexico, Russia, and Vietnam. Increasing the speed limit would significantly shorten the miners' travel time to their workplace, and thus extend the effective working time. Such an approach is economically justified; however, attention should be paid to the safety of the suspended monorail operator and the transported miners [2]. Currently, the suspended monorail sets used to transport the crew are not equipped with elements protecting people against injuries (e.g., seat belts, energy absorbing linings, and airbags) during emergency situations, such as emergency braking of the suspended monorail. During emergency braking, the braking systems, appropriately selected at the configuring stage of the transportation set, are activated [3]. This usually results in the stopping of the entire suspended monorail set on a short distance, which does not exceed several meters. In such cases, significant deceleration occurs, which causes dynamic overloads, affecting both people [4-9] and the entire suspended monorail set and its route [4-7]. Pursuant to the provisions of Polish law, the activation of the brake trolley should ensure a braking deceleration of not less than $1 \mathrm{~m} / \mathrm{s}^{2}$ and not more than $10 \mathrm{~m} / \mathrm{s}^{2}$. A similar value of the maximum allowable braking deceleration for the operator and the transported crew, $9.81 \mathrm{~m} / \mathrm{s}^{2}$, is in force in the Slovenian regulations. These overloads can cause an injury if a miner hits the passenger cabin structure or in the case of failure, e.g., resulting from damage to the railway route or breaking one of its slings [10-12].It should also be noted that increasing the speed of a suspended monorail increases its kinetic energy, which is directly proportional to the squared speed, which additionally increases the scale of the problem described [4,5,13-21]. During the stand tests of emergency braking at the speed of $5 \mathrm{~m} / \mathrm{s}$, the formation of a beam of sparks and the exceeding of the permissible temperature of the brake pad surface were observed [22]. These phenomena significantly increase the risk of methane ignition and, consequently, may cause a serious accident $[23,24]$.

Tests related to the possibilities of improving safety during emergency braking, even at increased speeds of suspended monorails, allowed for development of a concept of a control algorithm ensuring a sequential method of braking. In the currently used emergency braking systems, the total braking force is released immediately after the brake is applied. In these systems, it is not possible to modulate the braking force depending on the weight of the transport set or the shape of the suspended monorail route (upward and downward). In practice, this means that in a situation when the transport set is light (without a load) and, additionally, if it moves downward, and there is a need for emergency braking, the maximum permissible braking deceleration values may be exceeded; the dynamic load of the slings of the railway route and the load of the roof support arches increase significantly. This can lead to dangerous situations that could cause serious accidents. This case is particularly dangerous in the context of the increased permissible maximum speed limit. The development of the concept of the sequential braking algorithm is an innovative approach to the emergency braking process. The aim of its use is to reduce the risk of adverse impacts on humans and the suspended monorail route. Thus, the development of a modern method of braking will contribute to the improvement of safety in emergency braking situations. The assumed braking sequence, according to the developed concept, consists in the activation of some braking systems (the first braking stage) at the moment of the control signal activating emergency braking. The first braking stage has a reduced braking force (e.g., 50\% of the required braking force). After the activation 
of the first stage, a decision is made, based on the analysis of the deceleration, whether to activate the second stage braking (maximum available braking force is applied) or not. The braking deceleration occurring after the activation of the first braking stage, regarding the given suspension monorail set, may change depending on the load (number of people transported) or the shape of the monorail route (horizontal, downward or upward inclination) [13,25-28]. The article presents a computational model of a suspended monorail with an algorithm of the sequential emergency braking. The next part of the article presents the results of numerical simulations during which the parameters of the braking algorithm were changed. The aim of these simulations was to identify the impact of changing parameters of the braking process control algorithm on the deceleration as well as the time and the distance of braking in the case of an emergency stop of the transportation set during crew movement. We conducted simulation tests because tests in the real condition were impossible due to the inability to drive at higher speeds $(5 \mathrm{~m} / \mathrm{s})$ in the mines, as well as the inability to regulate the braking force on the individual braking elements. The observations presented in the article are necessary for the correct adjusting of the braking algorithm. Based on the acquired knowledge, it will be possible to propose how to set parameters in the braking algorithm depending on the transport set or to make changes in the proportion of the braking force values in the first and second stage, e.g., $40 \%$ of the total braking force in the first stage and $60 \%$ in the second stage.

\section{Materials and Methods}

\subsection{Computational Model and Its Validation}

The computational model was developed to recreate the suspended monorail set on the test stand. The elaborated model consisted of two modules. The first one was the solid model of the monorail system. It consisted of solids connected by geometrical constraints, defined by 3D contacts, and vectors of forces and moments. This model was developed in an MSC.Adams software environment, which is dedicated to analyzing the kinematics and dynamics of multi-body systems [29]. This model consisted of an operator's cabin, two rack-and-pinion drives integrated with a multi-plate brake, a diesel-hydraulic pack, a cabin for moving people, and a brake trolley, as well as a $90 \mathrm{~m}$ long railway track consisting of $4 \mathrm{~m}$ long straight rail sections. Figure 1 shows the model of the suspended monorail and a view of the test stand.
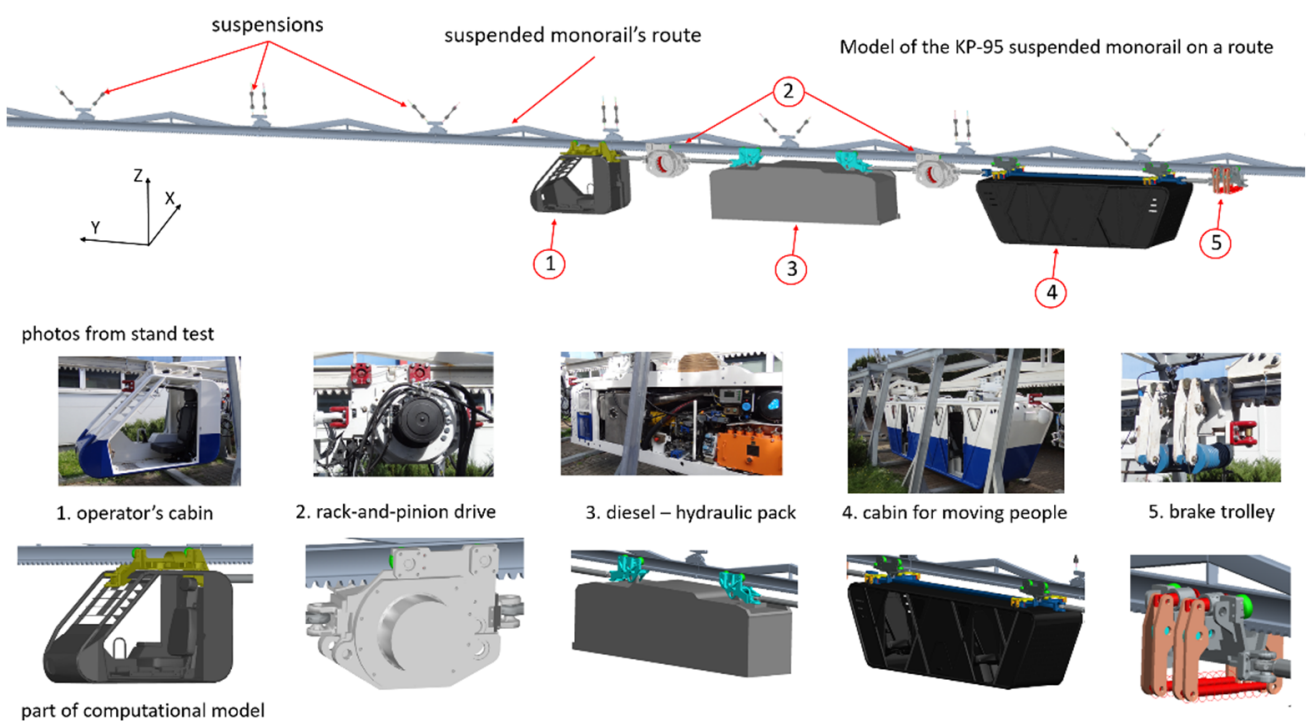

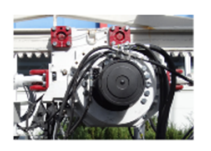

2. rack-and-pinion drive
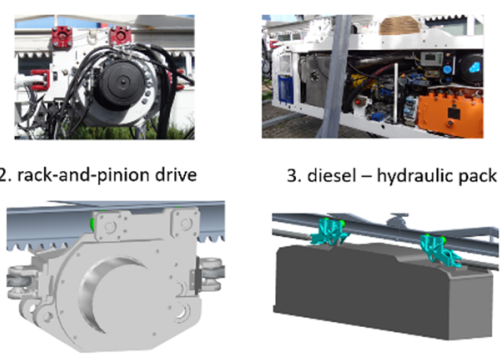

3. diesel-hydraulic pack

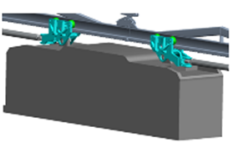

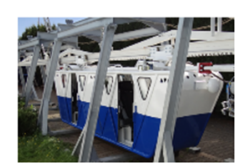

4. cabin for moving people

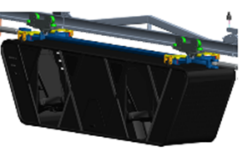

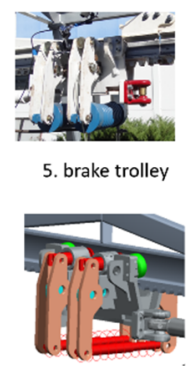

Figure 1. Components of the suspended monorail on the test stand, and the computational model of the KP-95 suspended monorail recreating the stand [13].

The second module was a model of the control system. The algorithm of the sequential emergency braking and the simulation control subsystem were implemented in this module, 
by defining such parameters as the maximum speed of the set, force vectors, and moments defined in the model, and by setting the parameters of the emergency braking algorithm. Defining the input and output signals of each of these modules enabled their connection and use of the co-simulation to simulate the emergency braking of a suspended monorail from the given speed, with different settings of the braking algorithm parameters [13,27,30-33]. The structure of the computational model and the signal flow, are presented in Figure 2.

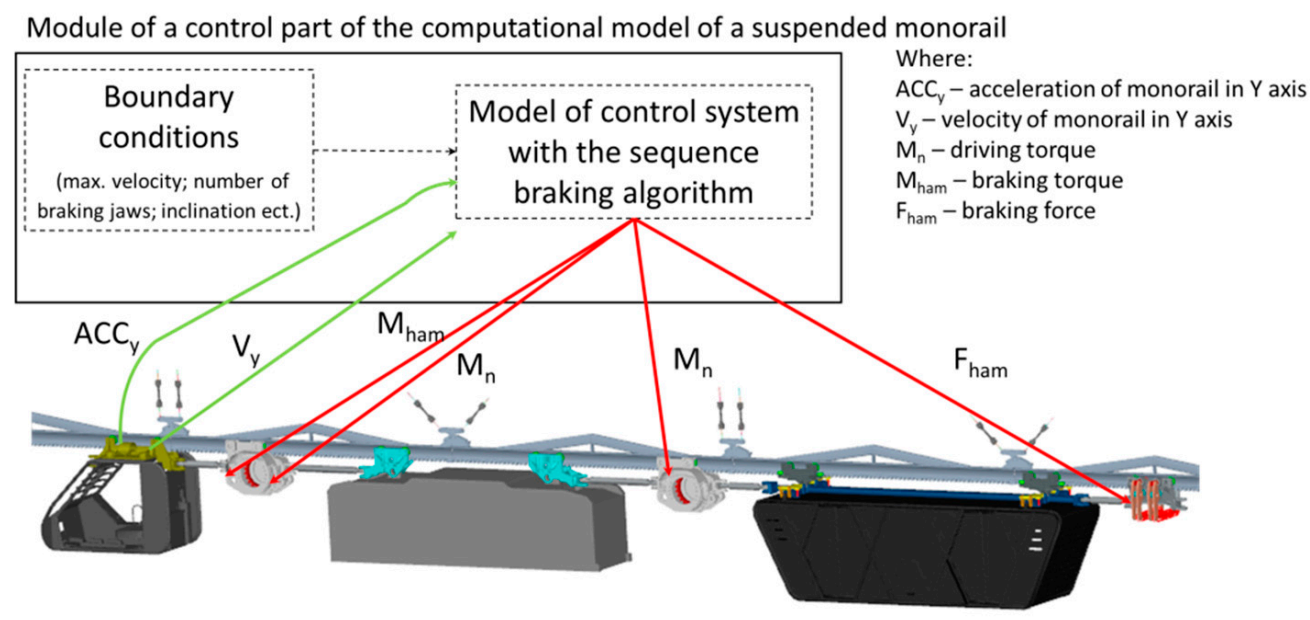

Module of a physical part of the computational model of a suspended monorail

Figure 2. The structure of the computational model and the signal flow between its modules [13].

The computational model was validated and adjusted by comparing the results of the measurements on the test stand and those calculated in numerical simulations. The following parameters were analyzed in the validation process:

- the acceleration recorded in the operator's cabin and in the cabin for moving people,

- vibrations expressed in root-mean square (RMS) recorded in the operator's cabin and in the cabin for moving people, and

- forces acting in the selected suspensions of the monorail route.

The results of the computational model validation process were presented in the European project report [13] and in previous publications by the authors [27,34].

\subsection{Concept of Sequential Braking Algorithm}

The reason for developing the control algorithm was to adjust the braking force to the conditions of emergency braking to ensure effective stopping of the suspended monorail set, while minimizing the risk of exceeding the permissible overload affecting the personnel in the cabin and the monorail operator. We suggested the sequential method of activating the brakes. We assumed that the activation of the second stage of braking depended on the deceleration within a certain time after the activation of the first stage of braking. At the first stage of braking, the braking trolley was used where the braking force was the result of the frictional coupling between the brake blocks and the rail. The second stage of braking used a multi-disc brake integrated with the rack-and-pinion drive. The algorithm presented in Figure 3 was used in the simulation of the emergency braking of the suspended monorail. 


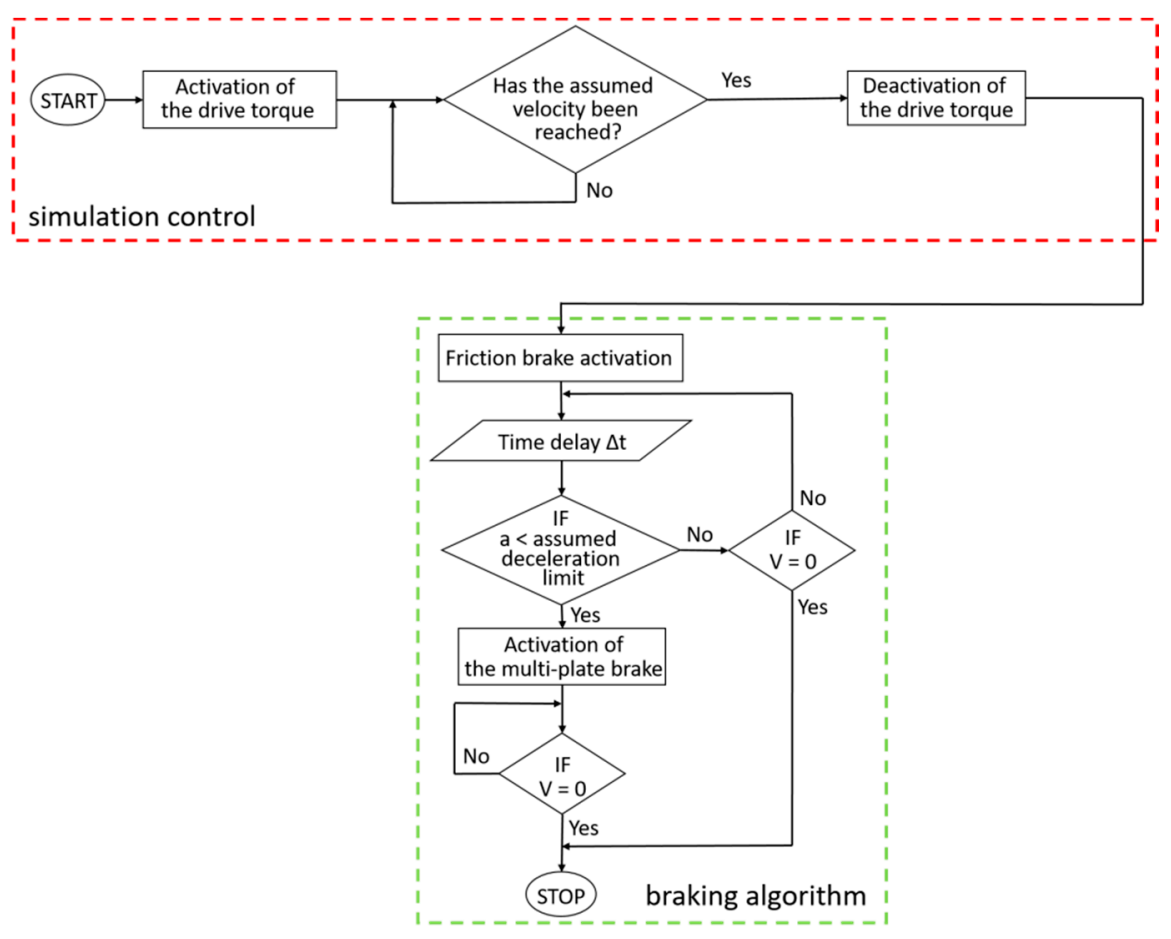

Figure 3. The block diagram of the emergency braking algorithm (the emergency braking algorithm is marked with the green dotted line-the algorithm responsible for the simulation control is marked by the red dotted line).

In the developed algorithm, a red rectangle marks the blocks used to control the simulation and related to speeding up to the assumed speed of the suspended monorail. A green rectangle marks the blocks describing the algorithm of a two-stage emergency braking. According to the presented algorithm, the monorail set was accelerated to the limit speed $\left(V_{y}\right)$ by activating the driving torques $\left(\mathrm{M}_{n}\right)$. The limit speed, which the monorail set should reach, was defined as one of the boundary conditions in the control system module. The condition if the assumed speed was reached was also controlled in this module. If the assumed speed was reached, the driving torques were deactivated, and the braking force vectors $\left(\mathrm{F}_{\mathrm{ham}}\right)$ were activated, pressing the brake pads against the rail; this is the first stage of braking. For the next stage, we calculated whether the deceleration of the suspended monorail set was greater or less than the assumed deceleration limit. This deceleration was measured after the given time delay. If the monorail deceleration was less than the limit, the braking torque $\left(\mathrm{M}_{\mathrm{ham}}\right)$, (the second stage of braking) was activated. If the recorded deceleration was greater or equal to the threshold deceleration, the second stage braking torque was not activated. We calculated when the monorail set stopped $\left(\mathrm{V}_{\mathrm{y}}=0\right)$, and then the simulation was terminated. This time delay was the difference between the moment of the activation of the braking force and the moment of the system response, i.e., its action on the rail with the assumed force in the form of a recorded waveform of decelerations of the suspended monorail. Without such a time delay, the second stage of the braking torque would always be activated.

\section{Results}

A series of numerical simulations enabled analysis of the impact of changing the parameters in the algorithm of the sequential braking of the monorail set on the emergency braking process. During the simulations, the braking deceleration threshold and the time delay, after which the deceleration was calculated, were changed. The settings of these parameters determined whether the second brake stage was activated or not. Numerical simulations were realized for two speeds at which the emergency braking started. The first of these speeds was $3 \mathrm{~m} / \mathrm{s}$ and the second was $5 \mathrm{~m} / \mathrm{s}$. Similar simulations of the emergency 
braking were carried out when the monorail set travelled on a route without inclination and on a route with a $30^{\circ}$ inclination. In each of the simulations, the braking deceleration, the braking time, and the braking distance were recorded. The maximum deceleration in the entire braking process as well as the maximum deceleration during the first braking stage (the maximum value recorded before the activation of the second braking stage) were analyzed.

Figure 4 shows the maximum braking deceleration recorded during numerical simulations of emergency braking from a speed of $3 \mathrm{~m} / \mathrm{s}$, on the horizontal route, as a function of the time delay, after which the condition of activating the second braking stage was calculated. These values are shown in relation to the three brake deceleration thresholds $\left(4 \mathrm{~m} / \mathrm{s}^{2}\right.$ (ACC4), $5 \mathrm{~m} / \mathrm{s}^{2}$ (ACC5), and $6 \mathrm{~m} / \mathrm{s}^{2}$ (ACC6)).

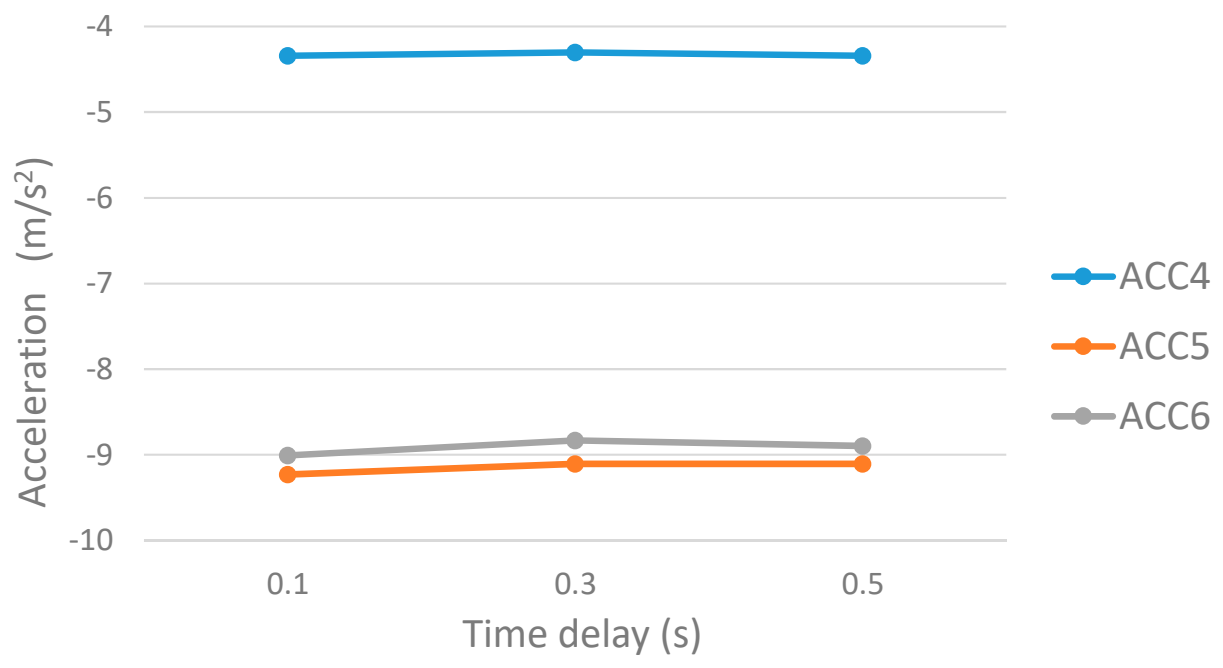

Figure 4. The maximum deceleration during emergency braking as a function of the time delay at braking from a speed of $3 \mathrm{~m} / \mathrm{s}$, on the horizontal route.

Figure 5 shows the braking distance recorded during numerical simulations of emergency braking from a speed of $3 \mathrm{~m} / \mathrm{s}$, on the horizontal route, as a function of the time delay, after which the condition of activating the second braking stage was calculated. These values are shown in relation to the three brake deceleration thresholds $\left(4 \mathrm{~m} / \mathrm{s}^{2}\right.$ (ACC4), $5 \mathrm{~m} / \mathrm{s}^{2}$ (ACC5), and $6 \mathrm{~m} / \mathrm{s}^{2}$ (ACC6)).

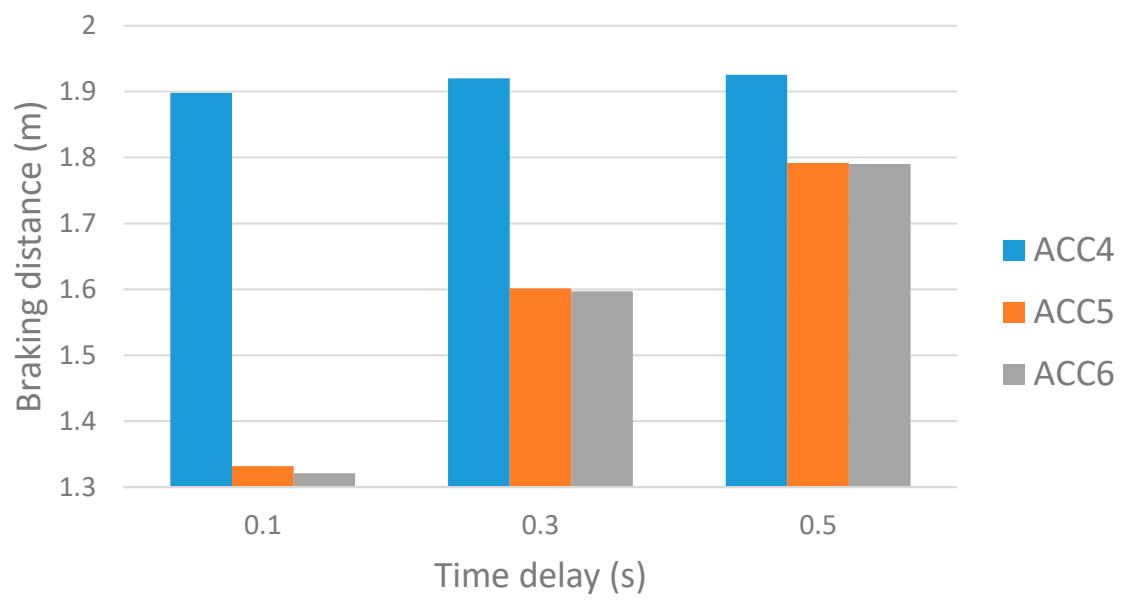

Figure 5. The distance of emergency braking as a function of the time delay at braking from a speed of $3 \mathrm{~m} / \mathrm{s}$, on the horizontal route. 
Table 1 provides the results recorded during the simulation of emergency braking of the suspended monorail set, from a speed of $3 \mathrm{~m} / \mathrm{s}$, on a horizontal route, in relation to different settings of the braking algorithm.

Table 1. Results of the simulations of emergency braking from a speed of $3 \mathrm{~m} / \mathrm{s}$, on a horizontal route, with different settings of the braking algorithm.

\begin{tabular}{|c|c|c|c|c|c|c|}
\hline $\begin{array}{c}\text { Braking } \\
\text { Deceleration } \\
\text { Threshold } \\
\left(\mathrm{m} / \mathrm{s}^{2}\right)\end{array}$ & $\begin{array}{l}\text { Delay in } \\
\text { Activation of } \\
\text { Second Stage } \\
\text { of Braking (s) }\end{array}$ & $\begin{array}{l}\text { Activation of } \\
\text { Second Stage } \\
\text { of Braking }\end{array}$ & $\begin{array}{c}\text { Maximum } \\
\text { Braking } \\
\text { Deceleration } \\
\left(\mathrm{m} / \mathrm{s}^{2}\right)\end{array}$ & $\begin{array}{c}\text { Maximum } \\
\text { Deceleration in the } \\
\text { First Stage of Braking } \\
\left(\mathrm{m} / \mathrm{s}^{2}\right)\end{array}$ & $\begin{array}{l}\text { Braking } \\
\text { Time (s) }\end{array}$ & $\begin{array}{l}\text { Braking } \\
\text { Distance } \\
\text { (m) }\end{array}$ \\
\hline 4 & 0.1 & $\mathrm{No}$ & 4.34 & - & 1.18 & 1.90 \\
\hline 4 & 0.3 & No & 4.30 & - & 1.18 & 1.92 \\
\hline 4 & 0.5 & No & 4.34 & - & 1.18 & 1.93 \\
\hline 5 & 0.1 & Yes & 9.23 & 4.34 & 0.73 & 1.33 \\
\hline 5 & 0.3 & Yes & 9.11 & 4.34 & 0.88 & 1.60 \\
\hline 5 & 0.5 & Yes & 9.12 & 4.34 & 0.99 & 1.79 \\
\hline 6 & 0.1 & Yes & 9.01 & 4.34 & 0.73 & 1.32 \\
\hline 6 & 0.3 & Yes & 8.83 & 4.34 & 0.87 & 1.60 \\
\hline 6 & 0.5 & Yes & 8.89 & 4.34 & 0.99 & 1.79 \\
\hline
\end{tabular}

Figure 6 shows the maximum braking deceleration recorded during numerical simulations of emergency braking from a speed of $5 \mathrm{~m} / \mathrm{s}$, on the horizontal route, as a function of the time delay, after which the condition of activating the second braking stage was calculated. These values are shown in relation to the three brake deceleration thresholds $\left(4 \mathrm{~m} / \mathrm{s}^{2}\right.$ (ACC4), $5 \mathrm{~m} / \mathrm{s}^{2}$ (ACC5), and $6 \mathrm{~m} / \mathrm{s}^{2}$ (ACC6)).

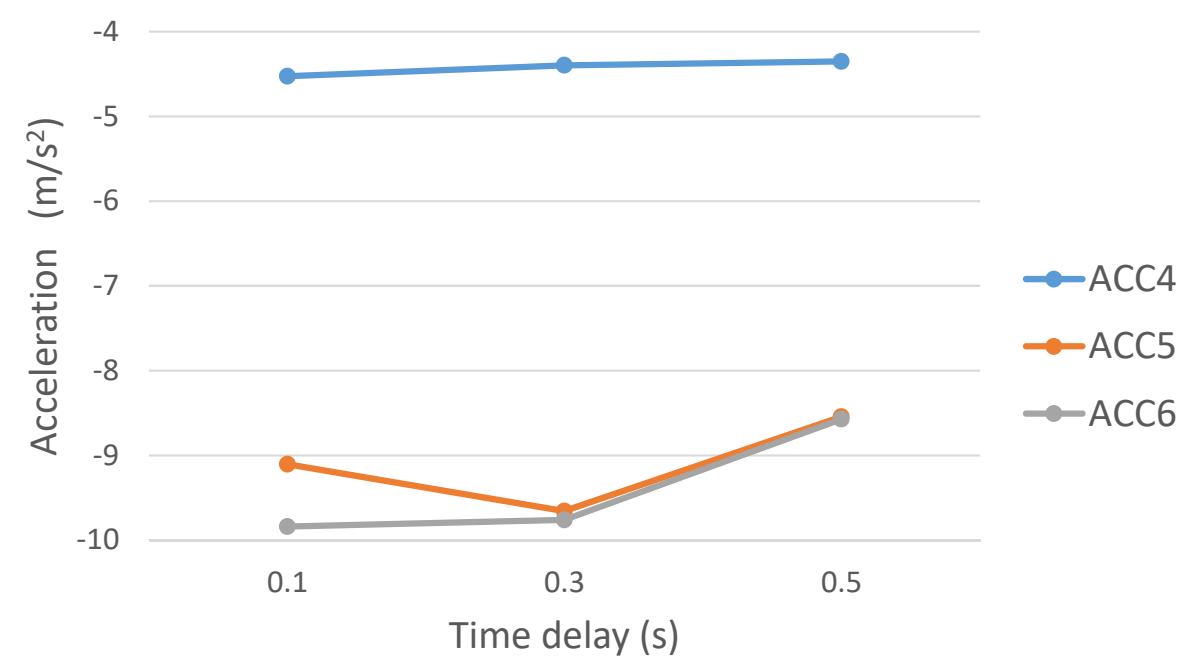

Figure 6. The maximum deceleration during emergency braking as a function of the time delay at braking from a speed of $5 \mathrm{~m} / \mathrm{s}$, on the horizontal route.

Figure 7 shows the braking distance recorded during numerical simulations of emergency braking from a speed of $5 \mathrm{~m} / \mathrm{s}$, on the horizontal route, as a function of the time delay, after which the condition of activating the second braking stage was calculated. These values are shown in relation to the three brake deceleration thresholds $\left(4 \mathrm{~m} / \mathrm{s}^{2}\right.$ (ACC4), $5 \mathrm{~m} / \mathrm{s}^{2}$ (ACC5), and $6 \mathrm{~m} / \mathrm{s}^{2}$ (ACC6)). 


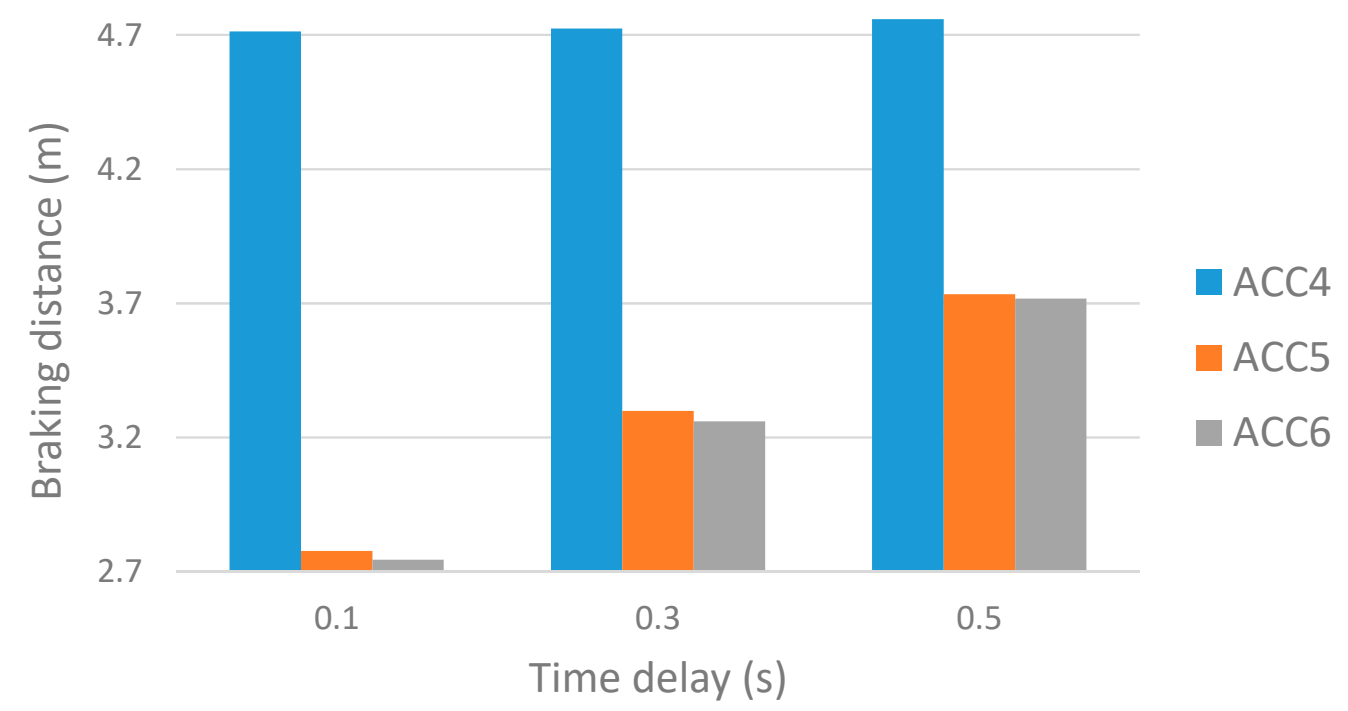

Figure 7. The distance of emergency braking as a function of the time delay at braking from a speed of $5 \mathrm{~m} / \mathrm{s}$, on the horizontal route.

Table 2 provides the results recorded during the simulation of emergency braking of the suspended monorail set, from a speed of $3 \mathrm{~m} / \mathrm{s}$, on a horizontal route, in relation to different settings of the braking algorithm.

Table 2. Results of the simulations of emergency braking from a speed of $5 \mathrm{~m} / \mathrm{s}$, on a horizontal route, with different settings of the braking algorithm.

\begin{tabular}{|c|c|c|c|c|c|c|}
\hline $\begin{array}{c}\text { Braking } \\
\text { Deceleration } \\
\text { Threshold } \\
\left(\mathrm{m} / \mathrm{s}^{2}\right)\end{array}$ & $\begin{array}{c}\text { Delay in } \\
\text { Activation of } \\
\text { Second Stage } \\
\text { of Braking (s) }\end{array}$ & $\begin{array}{l}\text { Activation of } \\
\text { Second Stage } \\
\text { of Braking }\end{array}$ & $\begin{array}{l}\text { Maximum } \\
\text { Braking } \\
\text { Deceleration } \\
\left(\mathrm{m} / \mathrm{s}^{2}\right)\end{array}$ & $\begin{array}{l}\text { Maximum } \\
\text { Deceleration in the } \\
\text { first Stage of Braking } \\
\qquad\left(\mathrm{m} / \mathrm{s}^{2}\right)\end{array}$ & $\begin{array}{l}\text { Braking } \\
\text { Time (s) }\end{array}$ & $\begin{array}{c}\text { Braking } \\
\text { Distance (s) }\end{array}$ \\
\hline 4 & 0.1 & No & 4.53 & - & 1.84 & 4.71 \\
\hline 4 & 0.3 & No & 4.40 & - & 1.85 & 4.72 \\
\hline 4 & 0.5 & No & 4.35 & - & 1.85 & 4.76 \\
\hline 5 & 0.1 & Yes & 9.10 & 3.14 & 0.92 & 2.78 \\
\hline 5 & 0.3 & Yes & 9.66 & 3.66 & 1.17 & 3.30 \\
\hline 5 & 0.5 & Yes & 8.55 & 3.65 & 1.17 & 3.73 \\
\hline 6 & 0.1 & Yes & 9.84 & 3.51 & 0.86 & 2.75 \\
\hline 6 & 0.3 & Yes & 9.76 & 3.62 & 1.16 & 3.26 \\
\hline 6 & 0.5 & Yes & 8.57 & 3.65 & 1.17 & 3.72 \\
\hline
\end{tabular}

Figure 8 shows the maximum braking deceleration recorded during numerical simulations of emergency braking from a speed of $3 \mathrm{~m} / \mathrm{s}$, on an inclined downward route of a $30^{\circ}$ angle, as a function of the time delay, after which the condition of activating the second braking stage was calculated. These values are shown in relation to the three brake deceleration thresholds $\left(4 \mathrm{~m} / \mathrm{s}^{2}\right.$ (ACC4), $5 \mathrm{~m} / \mathrm{s}^{2}$ (ACC5), and $6 \mathrm{~m} / \mathrm{s}^{2}$ (ACC6)).

Figure 9 shows the braking distance recorded during numerical simulations of emergency braking from a speed of $3 \mathrm{~m} / \mathrm{s}$, on an inclined downward route of $30^{\circ}$, as a function of the time delay, after which the condition of activating the second braking stage was calculated. These values are shown in relation to the three brake deceleration thresholds $\left(4 \mathrm{~m} / \mathrm{s}^{2}\right.$ (ACC4), $5 \mathrm{~m} / \mathrm{s}^{2}$ (ACC5), and $6 \mathrm{~m} / \mathrm{s}^{2}$ (ACC6)).

Table 3 provides the results recorded during the simulation of the emergency braking of the suspended monorail set, from a speed of $3 \mathrm{~m} / \mathrm{s}$, on a route inclined downward at a $30^{\circ}$ angle, in relation to different settings of the braking algorithm. 


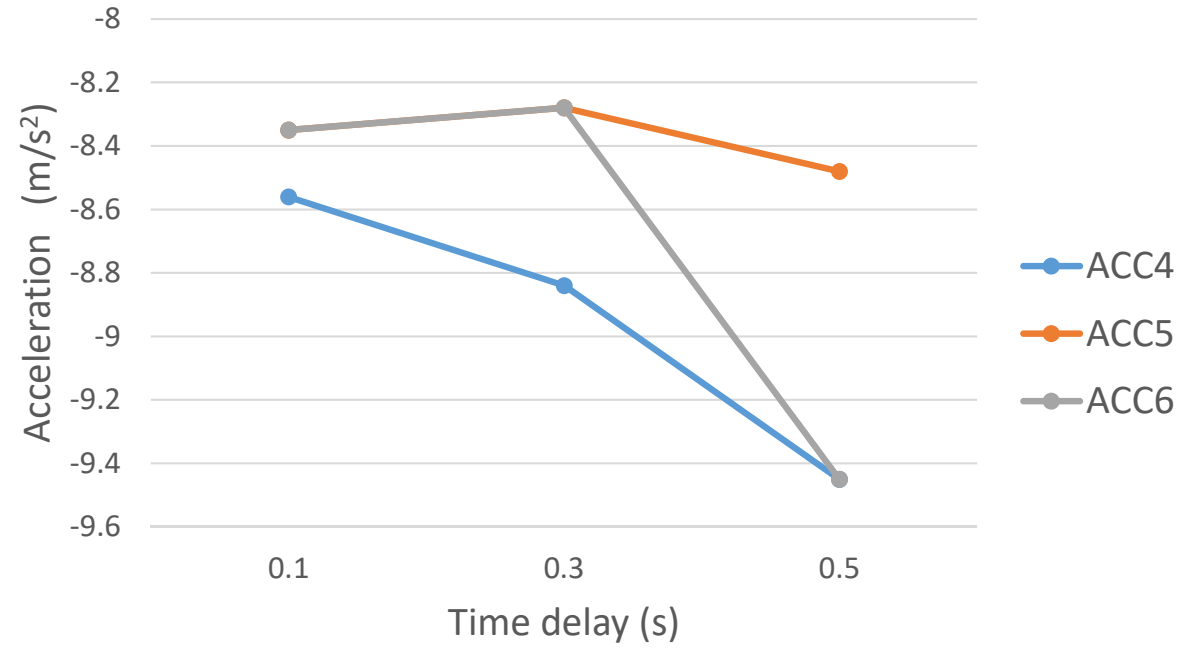

Figure 8. The maximum deceleration during emergency braking as a function of the time delay at braking from a speed of $3 \mathrm{~m} / \mathrm{s}$, on a route inclined downward at a $30^{\circ}$ angle.

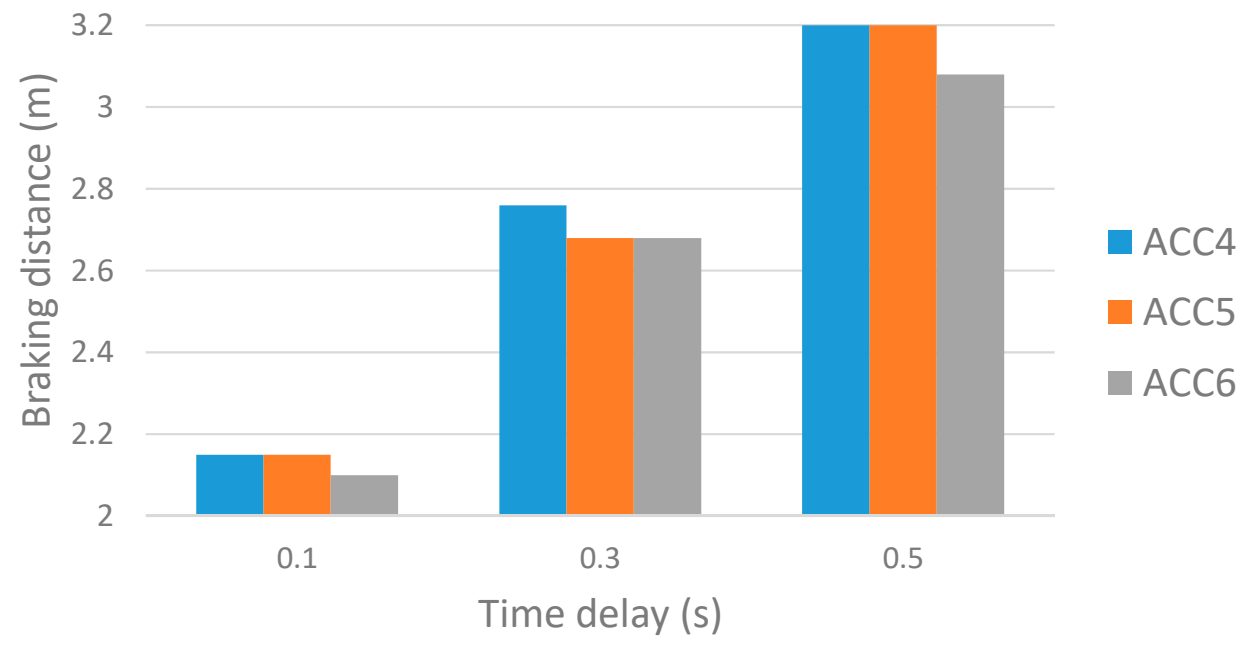

Figure 9. The distance of emergency braking as a function of the time delay at braking from a speed of $3 \mathrm{~m} / \mathrm{s}$, on a route inclined downward at a $30^{\circ}$ angle.

Table 3. Results of the simulations of emergency braking from a speed of $3 \mathrm{~m} / \mathrm{s}$, on a route inclined downward at a $30^{\circ}$ angle, with different settings of the braking algorithm.

\begin{tabular}{|c|c|c|c|c|c|c|}
\hline $\begin{array}{c}\text { Braking } \\
\text { Deceleration } \\
\text { Threshold } \\
\left(\mathrm{m} / \mathrm{s}^{2}\right)\end{array}$ & $\begin{array}{c}\text { Delay in } \\
\text { Activation of } \\
\text { Second Stage } \\
\text { of Braking (s) }\end{array}$ & $\begin{array}{l}\text { Activation of } \\
\text { Second Stage } \\
\text { of Braking }\end{array}$ & $\begin{array}{c}\text { Maximum } \\
\text { Braking } \\
\text { Deceleration } \\
\left(\mathrm{m} / \mathrm{s}^{2}\right)\end{array}$ & $\begin{array}{l}\text { Maximum } \\
\text { Deceleration in the } \\
\text { First Stage of Braking } \\
\left(\mathrm{m} / \mathrm{s}^{2}\right)\end{array}$ & $\begin{array}{l}\text { Braking } \\
\text { Time (s) }\end{array}$ & $\begin{array}{c}\text { Braking } \\
\text { Distance (s) }\end{array}$ \\
\hline 4 & 0.1 & Yes & 8.56 & 0.87 & 0.95 & 2.15 \\
\hline 4 & 0.3 & Yes & 8.84 & 2.498 & 1.22 & 2.76 \\
\hline 4 & 0.5 & Yes & 9.45 & 3.57 & 1.24 & 3.2 \\
\hline 5 & 0.1 & Yes & 8.35 & 0.87 & 0.94 & 2.15 \\
\hline 5 & 0.3 & Yes & 8.28 & 1.60 & 1.12 & 2.68 \\
\hline 5 & 0.5 & Yes & 8.48 & 1.65 & 1.25 & 3.2 \\
\hline 6 & 0.1 & Yes & 8.35 & 0.87 & 0.94 & 2.1 \\
\hline 6 & 0.3 & Yes & 8.28 & 1.60 & 1.12 & 2.68 \\
\hline 6 & 0.5 & Yes & 9.45 & 3.57 & 1.24 & 3.08 \\
\hline
\end{tabular}


Figure 10 shows the maximum braking deceleration recorded during numerical simulations of emergency braking from a speed of $5 \mathrm{~m} / \mathrm{s}$, on a route inclined downward at a $30^{\circ}$ angle, as a function of the time delay, after which the condition of activating the second braking stage was calculated. These values are shown in relation to the three brake deceleration thresholds $\left(4 \mathrm{~m} / \mathrm{s}^{2}\right.$ (ACC4), $5 \mathrm{~m} / \mathrm{s}^{2}$ (ACC5), and $6 \mathrm{~m} / \mathrm{s}^{2}$ (ACC6)).

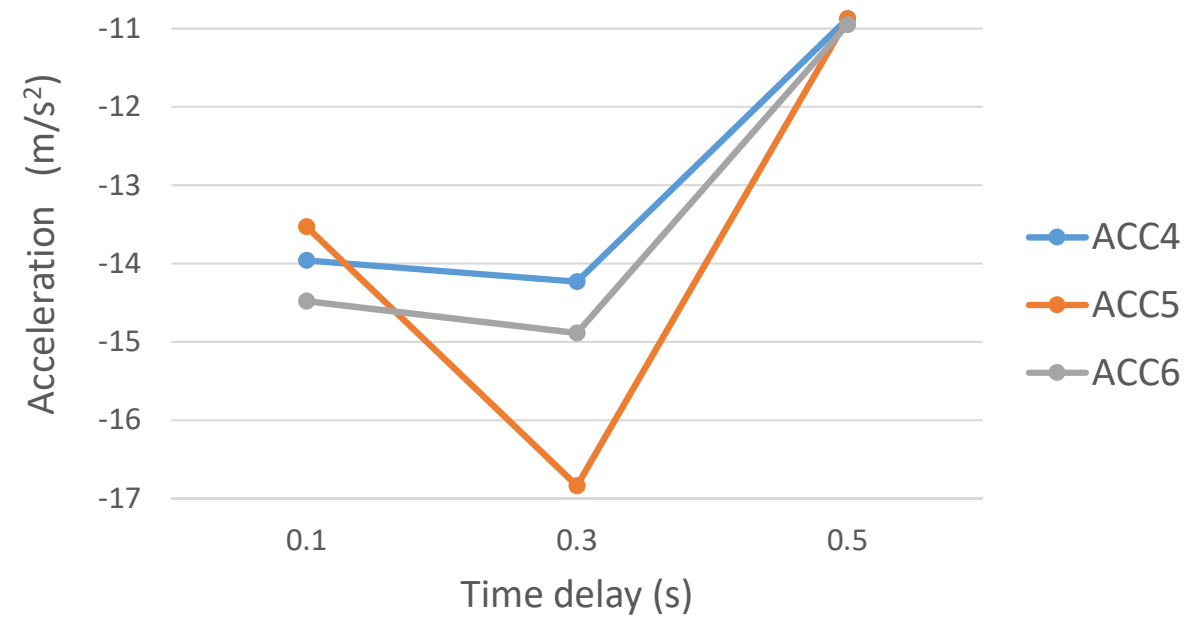

Figure 10. The maximum deceleration during emergency braking as a function of the time delay at braking from a speed of $5 \mathrm{~m} / \mathrm{s}$, on a route inclined downward at a $30^{\circ}$ angle.

Figure 11 shows the braking distance recorded during numerical simulations of emergency braking from a speed of $5 \mathrm{~m} / \mathrm{s}$, on an inclined route of $30^{\circ}$, as a function of the time delay, after which the condition of activating the second braking stage was calculated. These values are shown in relation to the three brake deceleration thresholds $\left(4 \mathrm{~m} / \mathrm{s}^{2}\right.$ (ACC4), $5 \mathrm{~m} / \mathrm{s}^{2}$ (ACC5), and $6 \mathrm{~m} / \mathrm{s}^{2}$ (ACC6).

\section{5}

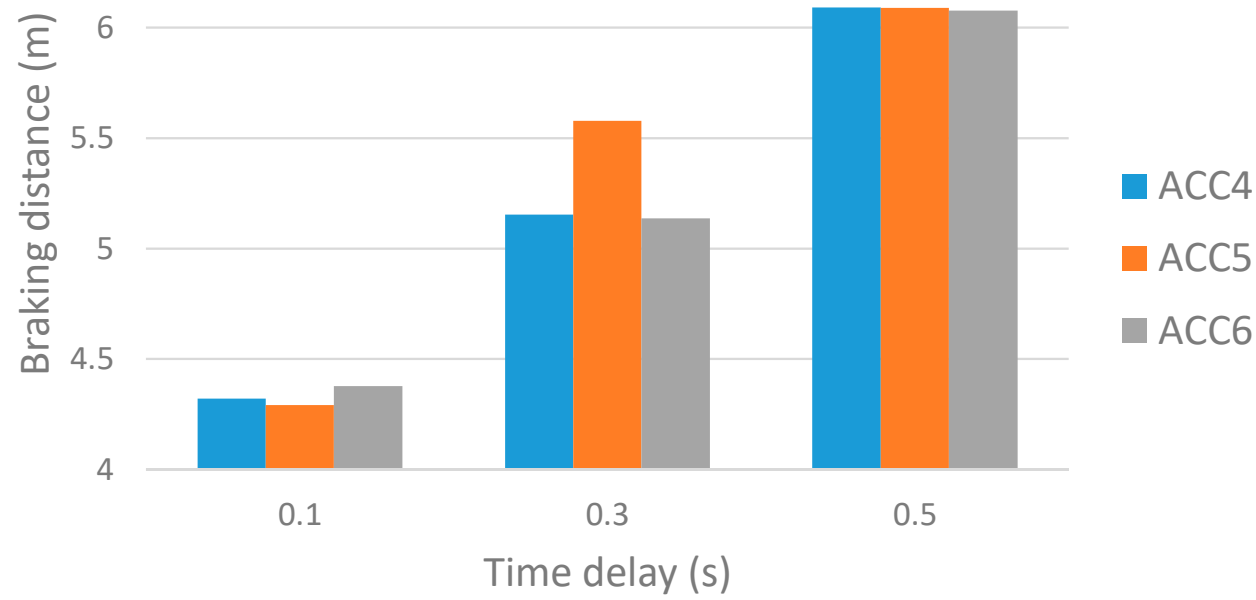

Figure 11. The distance of emergency braking as a function of the time delay at braking from a speed of $5 \mathrm{~m} / \mathrm{s}$, on a route inclined at a $30^{\circ}$ angle.

Table 4 provides the results recorded during the simulations of the emergency braking of the suspended monorail set, from a speed of $5 \mathrm{~m} / \mathrm{s}$, on a route inclined downward at a $30^{\circ}$ angle, in relation to different settings of the braking algorithm. 
Table 4. Results of the simulations of emergency braking from a speed of $5 \mathrm{~m} / \mathrm{s}$, on a route inclined downward at a $30^{\circ}$ angle, with different settings of the braking algorithm.

\begin{tabular}{|c|c|c|c|c|c|c|}
\hline $\begin{array}{c}\text { Braking } \\
\text { Deceleration } \\
\text { Threshold } \\
\left(\mathrm{m} / \mathrm{s}^{2}\right)\end{array}$ & $\begin{array}{l}\text { Delay in } \\
\text { Activation of } \\
\text { Second Stage } \\
\text { of Braking (s) }\end{array}$ & $\begin{array}{l}\text { Activation of } \\
\text { Second Stage } \\
\text { of Braking }\end{array}$ & $\begin{array}{c}\text { Maximum } \\
\text { Braking } \\
\text { Deceleration } \\
\left(\mathrm{m} / \mathrm{s}^{2}\right)\end{array}$ & $\begin{array}{c}\text { Maximum } \\
\text { Deceleration in the } \\
\text { First Stage of Braking } \\
\left(\mathrm{m} / \mathrm{s}^{2}\right)\end{array}$ & $\begin{array}{l}\text { Braking } \\
\text { Time (s) }\end{array}$ & $\begin{array}{c}\text { Braking } \\
\text { Distance } \\
\quad(\mathrm{m})\end{array}$ \\
\hline 4 & 0.1 & Yes & 13.96 & 3.25 & 1.62 & 4.32 \\
\hline 4 & 0.3 & Yes & 14.23 & 3.43 & 1.72 & 5.15 \\
\hline 4 & 0.5 & Yes & 10.87 & 3.43 & 1.61 & 6.12 \\
\hline 5 & 0.1 & Yes & 13.53 & 2.86 & 1.61 & 4.29 \\
\hline 5 & 0.3 & Yes & 16.84 & 4.09 & 1.77 & 5.58 \\
\hline 5 & 0.5 & Yes & 10.87 & 3.29 & 1.61 & 5.93 \\
\hline 6 & 0.1 & Yes & 14.48 & 3.43 & 1.57 & 4.38 \\
\hline 6 & 0.3 & Yes & 14.89 & 3.43 & 1.73 & 5.14 \\
\hline 6 & 0.5 & Yes & 10.95 & 3.45 & 1.61 & 6.08 \\
\hline
\end{tabular}

Figures 12-14 show a comparison of the braking distance at different threshold values of the first stage of braking deceleration, the delay in activation of the second stage of braking, the speed from which the set was braked, and the inclination angle of the route.

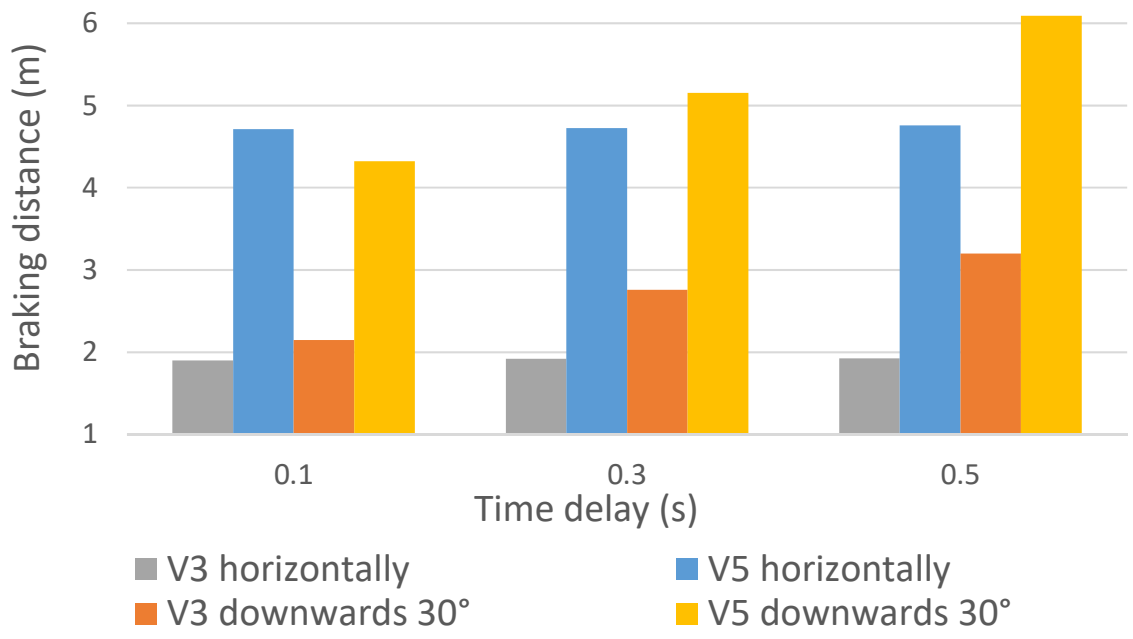

Figure 12. The braking distance at different boundary conditions in relation to the deceleration threshold equal to $4 \mathrm{~m} / \mathrm{s}^{2}$.

In the next stage of the work, another group of simulations, in which the forces of pressing the jaws against the rail web and the number of actively braking jaws were changed, were aimed at observing the impact of the first degree braking force changes on the deceleration during emergency braking, the braking distance, and the braking time. Braking with two pairs of jaws and with only one pair of jaws was simulated. In each case, the braking was simulated with the full clamping force of the jaws $(12,500 \mathrm{~N})$, with a force $50 \%$ lower $(6250 \mathrm{~N})$, and a force lower by $75 \%(3125 \mathrm{~N})$. The time delay for the activation of the second stage of braking was $0.5 \mathrm{~s}$. Moreover, for reduced forces $(50 \%$ and $25 \%$ of the initial value), simulations were carried out with the activation time delay of the second stage equal to $1 \mathrm{~s}$. All simulations calculated braking from a speed of $5 \mathrm{~m} / \mathrm{s}$. The simulation results are presented in Table 5 . 


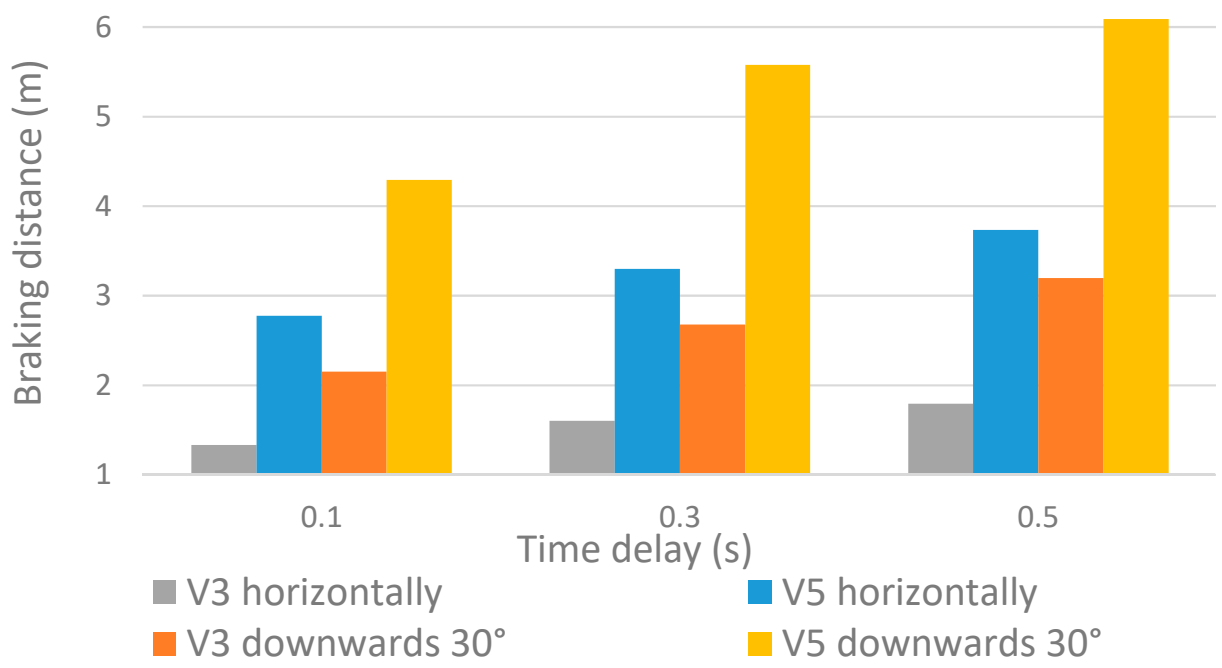

Figure 13. The braking distance at different boundary conditions in relation to the deceleration threshold equal to $5 \mathrm{~m} / \mathrm{s}^{2}$.

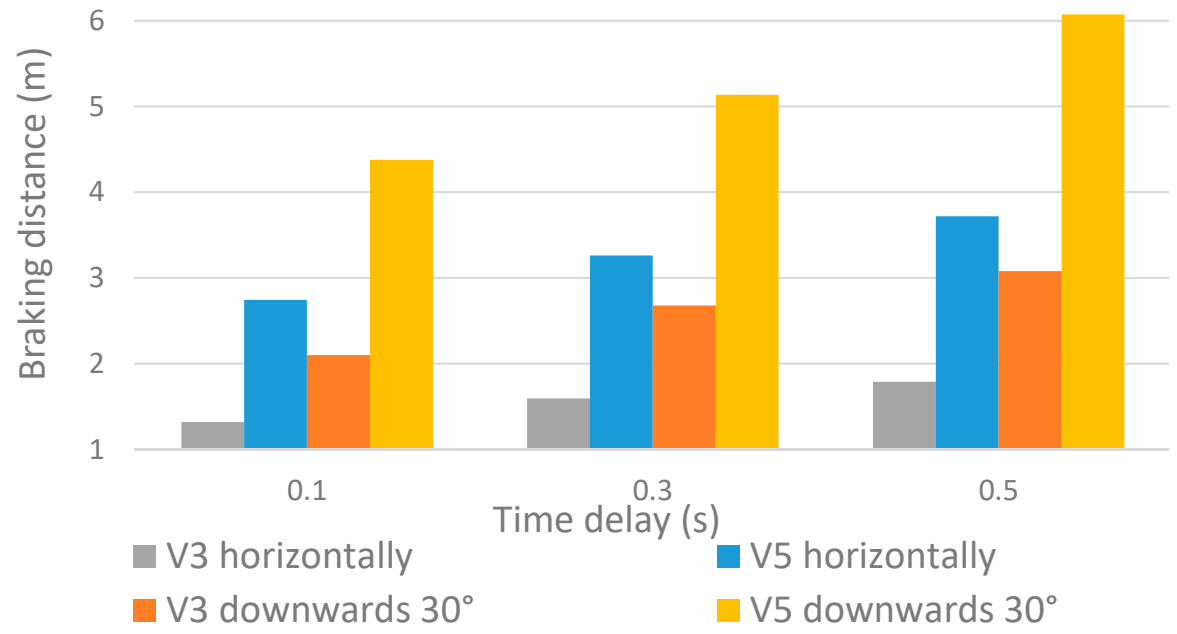

Figure 14. The braking distance at different boundary conditions in relation to the deceleration threshold equal to $6 \mathrm{~m} / \mathrm{s}^{2}$.

Table 5. Results of the simulations of emergency braking with reduced braking forces at the first stage of braking.

\begin{tabular}{|c|c|c|c|c|c|c|c|c|}
\hline $\begin{array}{l}\text { Force } \\
\text { Pressing the } \\
\text { Jaw to a Rail } \\
\text { (N) }\end{array}$ & $\begin{array}{c}\text { Number } \\
\text { of } \\
\text { Active } \\
\text { Braking } \\
\text { Jaws } \\
\text { Pairs }\end{array}$ & $\begin{array}{c}\text { Deceleration } \\
\text { Threshold } \\
\left(\mathrm{m} / \mathrm{s}^{2}\right)\end{array}$ & $\begin{array}{c}\text { Delay in } \\
\text { Activation } \\
\text { of Second } \\
\text { Stage } \\
\text { Braking (s) }\end{array}$ & $\begin{array}{c}\text { Activation } \\
\text { of Second } \\
\text { Stage } \\
\text { Braking }\end{array}$ & $\begin{array}{c}\text { Maximum } \\
\text { Deceleration } \\
\left(\mathrm{m} / \mathrm{s}^{2}\right)\end{array}$ & $\begin{array}{c}\text { Maximum } \\
\text { Decelerationat } \\
\text { First Stage of } \\
\text { Braking }\left(\mathrm{m} / \mathrm{s}^{2}\right)\end{array}$ & $\begin{array}{l}\text { Braking } \\
\text { Time (s) }\end{array}$ & $\begin{array}{c}\text { Braking } \\
\text { Distance (m) }\end{array}$ \\
\hline 12,500 & 1 & 6 & 0.5 & Yes & 8.57 & 3.65 & 1.17 & 3.72 \\
\hline 6250 & 1 & 6 & 0.5 & Yes & 7.74 & 2.07 & 1.39 & 4.74 \\
\hline 3125 & $\begin{array}{l}1 \\
1\end{array}$ & 6 & 0.5 & Yes & 8.68 & 1.69 & 1.58 & 5.34 \\
\hline 6250 & 1 & 6 & 1 & Yes & 8.53 & 2.44 & 1.86 & 6.30 \\
\hline 3125 & 1 & 6 & 1 & Yes & 7.45 & 2.32 & 2.05 & 7.35 \\
\hline 12,500 & 2 & 6 & 0.5 & No & 7.35 & - & 1.0 & 2.84 \\
\hline 6250 & 2 & 6 & 0.5 & No & 6.11 & - & 2.02 & 5.1 \\
\hline 3125 & 2 & 6 & 0.5 & Yes & 7.69 & 1.93 & 1.39 & 4.78 \\
\hline 6250 & 2 & 6 & 1 & Yes & 8.58 & 4.25 & 1.53 & 4.77 \\
\hline 3125 & 2 & 6 & 1 & Yes & 8.10 & 2.39 & 1.87 & 6.36 \\
\hline
\end{tabular}


Figure 15 shows the relationship between the braking distance and the braking force of the first braking stage and the delay in the activation of the second braking stage.

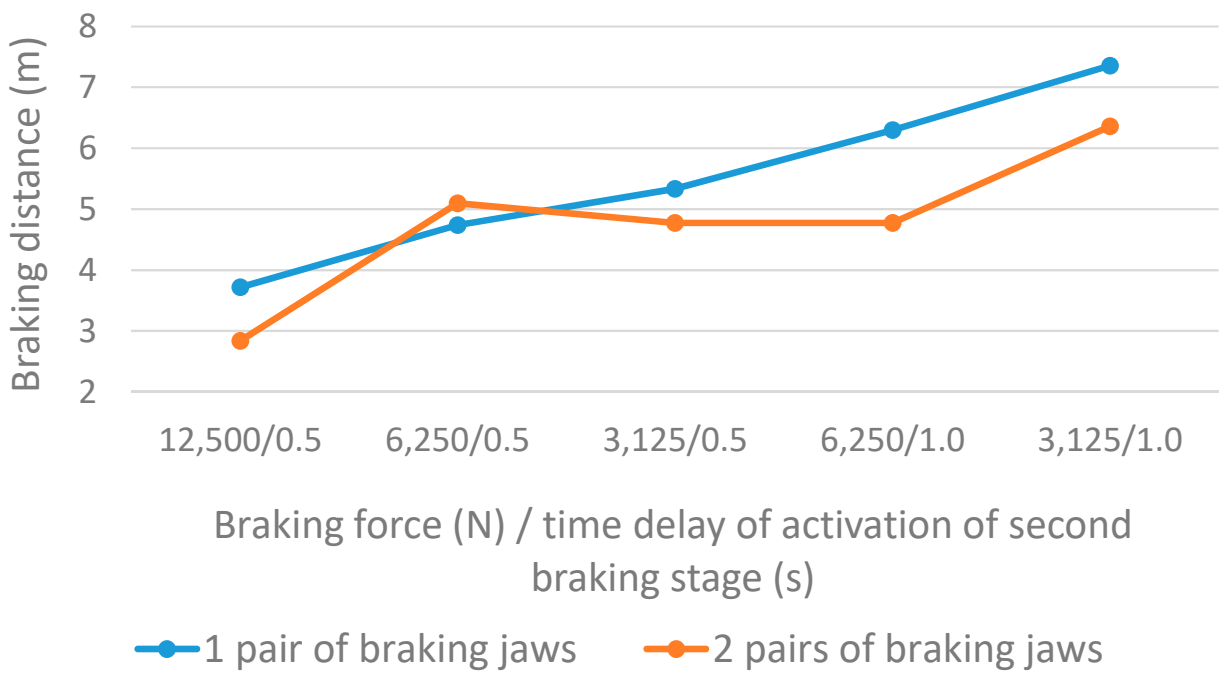

Figure 15. The relationship between the braking distance and the force of the first stage braking and the time delay in the second stage braking.

Figure 16 shows the maximum deceleration recorded during the simulation of emergency two-stage braking as a function of the braking force and the time delay in the activation of the second stage braking.

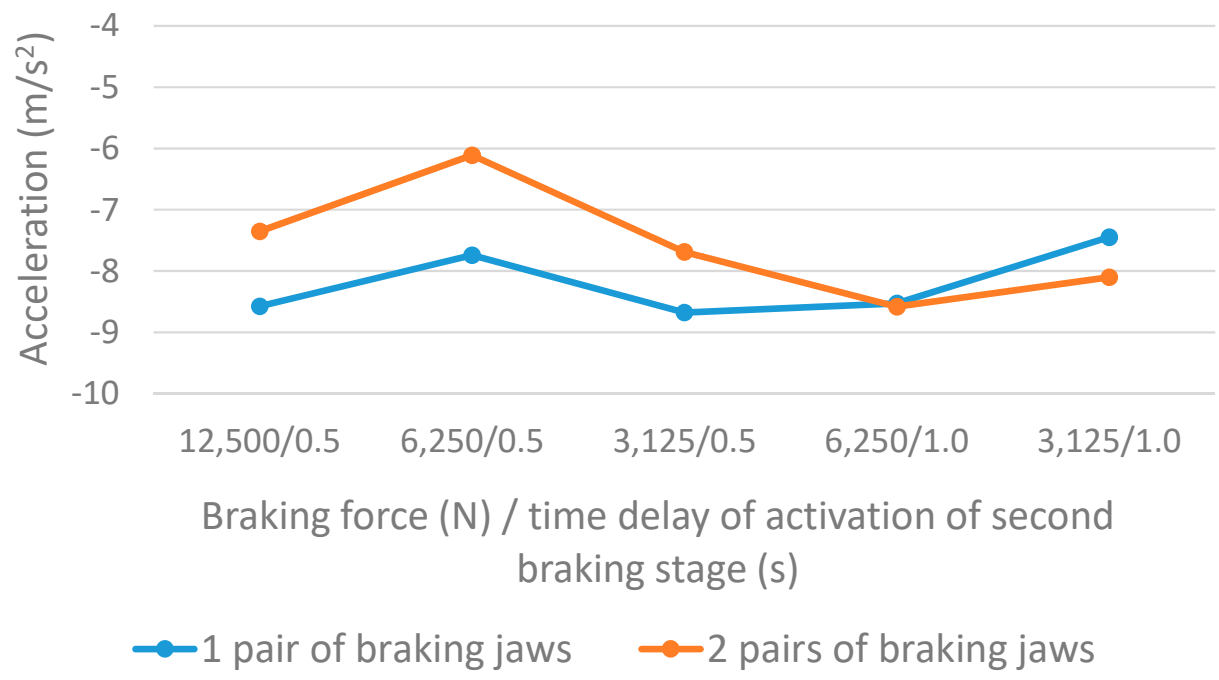

Figure 16. The maximum deceleration recorded during the simulation of emergency two-stage braking as a function of the braking force and the time delay in the activation of the second stage braking.

Figure 17 shows the accelerations recorded when simulating braking from a speed of $5 \mathrm{~m} / \mathrm{s}$ with one pair of jaws, different forces pressing the jaws against the rail, and a different delay in the activation of the second braking stage.

Figure 19 shows the accelerations recorded when braking from a speed of $5 \mathrm{~m} / \mathrm{s}$ with two pairs of jaws, with different forces pressing the jaws against the rail, and a different delay in the activation of the second braking stage. 


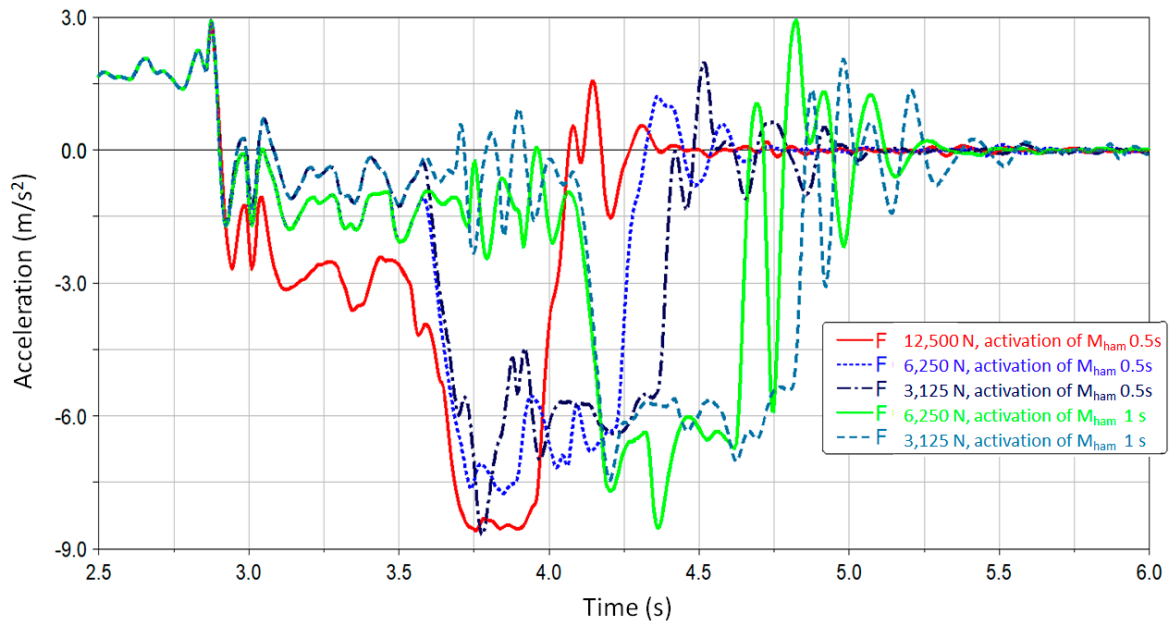

Figure 17. Waveforms of changes in the acceleration of the monorail cabin during emergency braking at different pressing forces of jaws and the time delay in the activation of the second stage of braking using one pair of jaws. Distances covered by the monorail during those simulations are given in Figure 18.

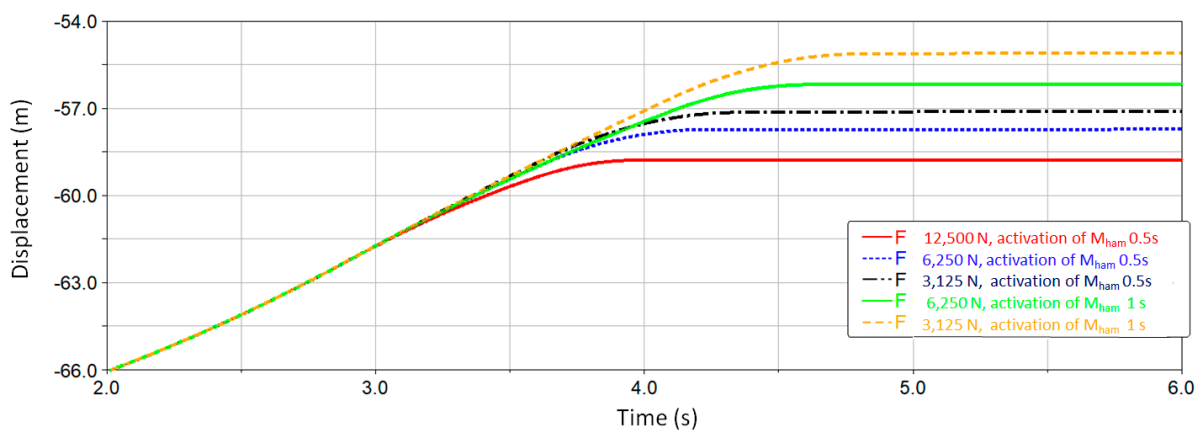

Figure 18. Distances covered by the monorail during simulations of emergency braking at different pressing forces of jaws and the time delay in the activation of the second stage of braking using one pair of jaws.

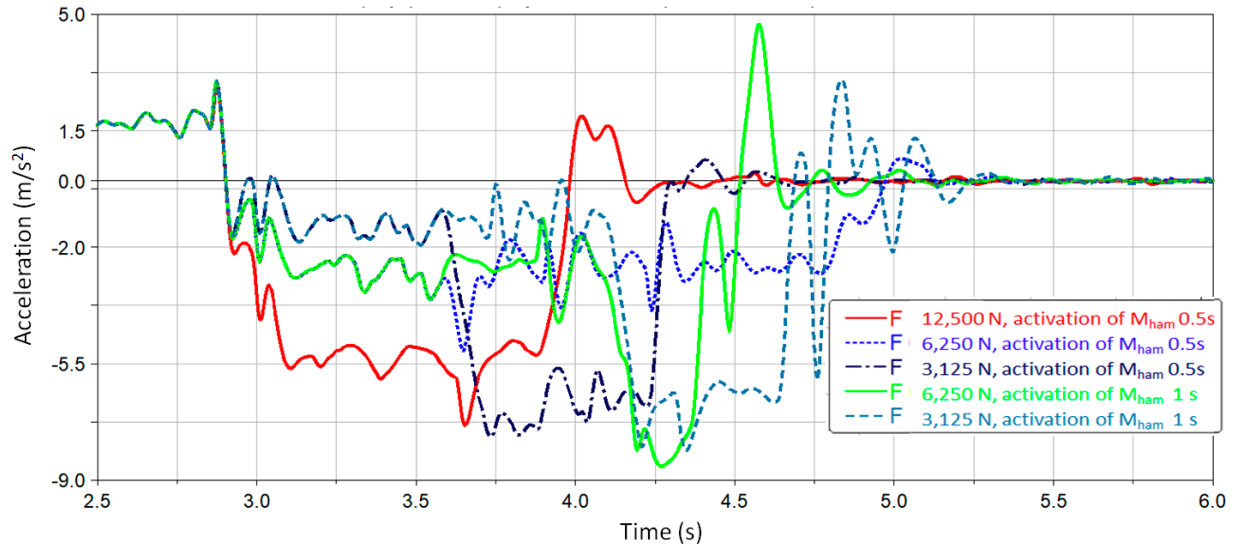

Figure 19. Waveforms of changes in the acceleration of the monorail cabin during emergency braking at different pressing forces of jaws and the time delay in the activation of the second stage of braking using two pairs of jaws. Braking distances of the monorail during those simulations are given in Figure 20. 


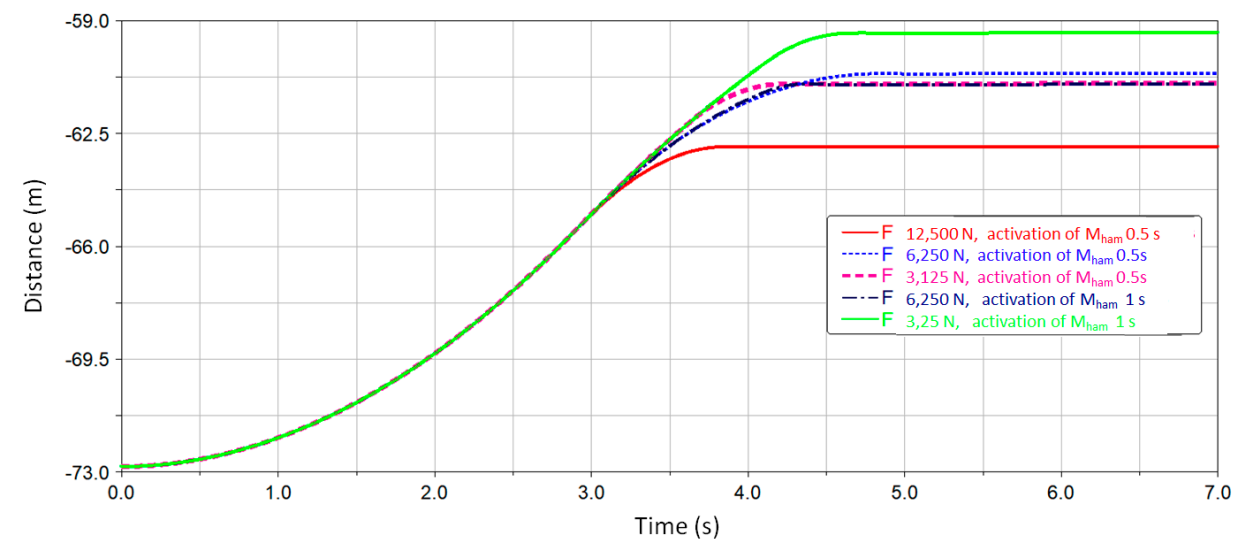

Figure 20. Distances covered by the monorail during simulations of emergency braking at different pressing forces of jaws and the time delay in the activation of the second stage of braking using two pairs of jaws.

Table 6 presents the maximum forces recorded in each suspension during the simulation of emergency braking from a speed of $5 \mathrm{~m} / \mathrm{s}$, with different forces pressing the jaws against the rail and different time delays in the activation of the second braking stage, as well as braking with one or two pairs of jaws. Figure 21 shows the markings of the suspensions of the suspended monorail route.

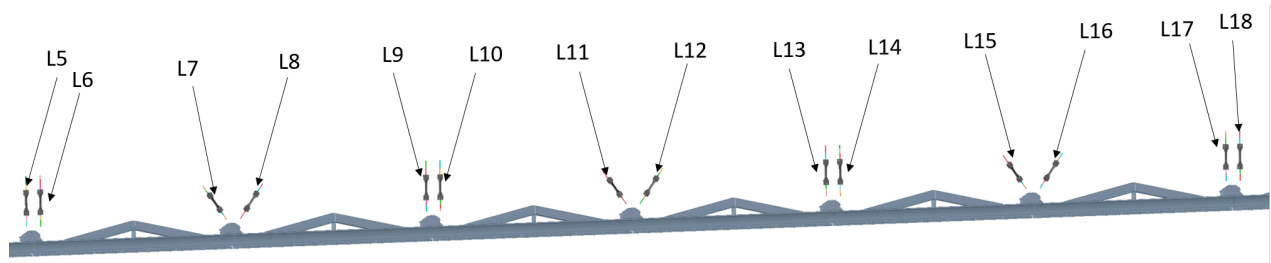

Figure 21. Markings of the suspensions of the monorail route.

Table 6 shows the maximum values of the forces in the suspensions. During emergency braking, the whole monorail route is able to move in the direction of the travel. During the movement of the route, some suspensions, especially those stabilizing the position of the route, become overloaded and others loosen. This is one reason for the dynamic overload of the suspension. Depending on the location of individual components on the rail, the character of the displacement of rails and loads on the suspensions may change. From this point of view, it seems that ensuring the appropriate condition of the route on the sections with an increased speed limit is necessary. 
Table 6. Maximum forces in suspensions at different forces pressing the jaws to a rail and different time delays in the activation of the second stage of braking.

\begin{tabular}{|c|c|c|c|c|c|c|c|c|c|c|c|}
\hline $\begin{array}{c}\text { Force } \\
\text { Pressing the } \\
\text { Jaws to a } \\
\text { Rail (N) }\end{array}$ & $\begin{array}{c}\text { Number } \\
\text { of Active } \\
\text { Pairs of } \\
\text { Jaws }\end{array}$ & $\begin{array}{c}\text { Deceleration } \\
\text { Threshold } \\
\left(\mathrm{m} / \mathrm{s}^{2}\right)\end{array}$ & $\begin{array}{l}\text { Time Delay in } \\
\text { Activation of } \\
\text { the Second } \\
\text { Stage of } \\
\text { Braking (s) }\end{array}$ & $\begin{array}{l}\text { Maximum } \\
\text { Force in } \\
\text { Suspension } \\
\text { L7 (N) }\end{array}$ & $\begin{array}{l}\text { Maximum } \\
\text { Force in } \\
\text { Suspension } \\
\text { L8 (N) }\end{array}$ & $\begin{array}{l}\text { Maximum } \\
\text { Force in } \\
\text { Suspension } \\
\text { L9 (N) }\end{array}$ & $\begin{array}{l}\text { Maximum } \\
\text { Force in } \\
\text { Suspension } \\
\text { L10 (N) }\end{array}$ & $\begin{array}{l}\text { Maximum } \\
\text { Force in } \\
\text { Suspension } \\
\text { L11 (N) }\end{array}$ & $\begin{array}{l}\text { Maximum } \\
\text { Force in } \\
\text { Suspension } \\
\text { L12 (N) }\end{array}$ & $\begin{array}{l}\text { Maximum } \\
\text { Force in } \\
\text { Suspension } \\
\text { L13 (N) }\end{array}$ & $\begin{array}{l}\text { Maximum } \\
\text { Force in } \\
\text { Suspension } \\
\text { L14 (N) }\end{array}$ \\
\hline 12,500 & 1 & 6 & 0.5 & 26,025 & 35,616 & 23,115 & 23,179 & 48,321 & 41,594 & 19,616 & 19,433 \\
\hline 6250 & 1 & 6 & 0.5 & 26,025 & 35,616 & 23,115 & 23,179 & 43,249 & 41,594 & 19,039 & 19,001 \\
\hline 3125 & 1 & 6 & 0.5 & 26,025 & 35,616 & 23,115 & 23,179 & 40,056 & 41,594 & 21,681 & 21,655 \\
\hline 6250 & 1 & 6 & 1 & 26,025 & 35,616 & 23,115 & 23,179 & 33,899 & 41,594 & 25,889 & 25,814 \\
\hline 12,500 & 2 & 6 & 0.5 & 25,506 & 35,359 & 22,290 & 22,354 & 45,407 & 40,040 & 16,027 & 16,111 \\
\hline 6250 & 2 & 6 & 0.5 & 25,506 & 35,359 & 22,290 & 22,354 & 37,197 & 40,040 & 19,081 & 18,877 \\
\hline 3125 & 2 & 6 & 0.5 & 25,506 & 35,359 & 22,290 & 22,354 & 41,932 & 40,040 & 19,842 & 19,265 \\
\hline 6250 & 2 & 6 & 1 & 25,509 & 35,359 & 22,270 & 22,334 & 35,592 & 40,070 & 23,441 & 23,362 \\
\hline 3125 & 2 & 6 & 1 & 25,506 & 35,359 & 22,290 & 22,354 & 36,898 & 40,040 & 27,465 & 27,435 \\
\hline
\end{tabular}




\section{Discussion}

The conceptualization of the algorithm for the sequential emergency braking of suspended monorails during the people movement in underground mine workings was described. Solving an extremely important safety issue, the method of braking aimed at minimizing the dynamic overload acting on the people in the monorail cabin Such overloads may cause an uncontrolled change of the position and the movement of the miner's body in the cabin, which may result in injuries. The results of the first numerical simulations aimed at analyzing the operation and the impact of the behavior of the monorail set during emergency braking at different parameters. Based on the simulations, we found the following:

- When braking from a speed of $3 \mathrm{~m} / \mathrm{s}$ on a horizontal route, setting the deceleration threshold to $4 \mathrm{~m} / \mathrm{s}^{2}$ caused the second stage of braking to not be activated. This resulted in an increase in the braking time, extending the braking distance, and reduced the deceleration affect.

- The highest deceleration during braking from a speed of $3 \mathrm{~m} / \mathrm{s}$ on a horizontal route was recorded for the following parameters: a deceleration threshold equal to $5 \mathrm{~m} / \mathrm{s}^{2}$ and a delay equal to $0.1 \mathrm{~s}$. The lowest deceleration was measured at the following settings: a threshold deceleration equal to $4 \mathrm{~m} / \mathrm{s}^{2}$ and a time delay equal to $0.3 \mathrm{~s}$.

- When braking from $5 \mathrm{~m} / \mathrm{s}$ on a horizontal route with a deceleration threshold of $4 \mathrm{~m} / \mathrm{s}^{2}$, the second stage of braking was not activated. If the second braking stage is not activated, the braking time increases and the braking distance increases too. The deceleration effect was reduced.

- The highest deceleration during braking from a speed of $5 \mathrm{~m} / \mathrm{s}$ on a horizontal route was recorded for the following parameters: a deceleration threshold equal to $6 \mathrm{~m} / \mathrm{s}^{2}$ and a time delay equal to $0.1 \mathrm{~s}$. The lowest deceleration was recorded at the following settings: a threshold deceleration equal to $4 \mathrm{~m} / \mathrm{s}^{2}$ and a delay equal to $0.5 \mathrm{~s}$.

- When downward braking at a $30^{\circ}$ angle, both braking stages were always activated, regardless of the speed and the deceleration threshold setting.

- The highest deceleration during the downward braking from a speed of $3 \mathrm{~m} / \mathrm{s}$ at a $30^{\circ}$ angle was recorded with the following parameters: a threshold deceleration equal to $4 \mathrm{~m} / \mathrm{s}^{2}$ and $6 \mathrm{~m} / \mathrm{s}^{2}$ and a time delay equal to $0.5 \mathrm{~s}$. In such cases, the highest deceleration was also recorded during the first braking stage. The lowest delay was recorded for the following settings: a threshold delay equal to $4 \mathrm{~m} / \mathrm{s}^{2}$ and $5 \mathrm{~m} / \mathrm{s}^{2}$ and a delay equal to $0.5 \mathrm{~s}$.

- The highest deceleration during the downward braking from a speed of $5 \mathrm{~m} / \mathrm{s}$ at a $30^{\circ}$ angle was recorded for the following parameters: a deceleration threshold equal to $5 \mathrm{~m} / \mathrm{s}^{2}$ and a delay equal to $0.3 \mathrm{~s}$. The lowest deceleration was recorded at the following settings: a threshold deceleration equal to $4 \mathrm{~m} / \mathrm{s}^{2}$ and $5 \mathrm{~m} / \mathrm{s}^{2}$ and a delay equal to $0.5 \mathrm{~s}$.

- Changes in the braking forces activated in the first emergency braking stage have an impact on the braking process. The appropriate selection of proportions between the force at the first and the second stage of braking, and the delay time of the second stage activation may allow the emergency braking process to be gentler, minimizing the deceleration effects on the human body.

\section{Conclusions}

The article presents an innovative approach to emergency braking of the suspended monorail in underground hard coal mines. The innovation of this approach consists in the novel use of sequential activation of braking elements that enables modulation of the braking force depending on the boundary conditions during emergency braking. During the braking process, the deceleration affects the operator and the personnel. The maximum deceleration can be seen in the acceleration diagrams as a peak. Use of the sequential emergency braking algorithm enables minimizing the braking decelerations acting on people in the monorail during emergency braking. In this way, the operator or 
the personnel injury risk is limited. For the best operation of the algorithm, it is necessary to select the appropriate settings of its parameters (decisive for the activation of the second braking stage), which are: the deceleration threshold and the delay. On the basis of the numerical simulations, it can be estimated that setting the delay time in the range from $0.3 \mathrm{~s}$ to $0.5 \mathrm{~s}$, and the deceleration threshold of $4 \mathrm{~m} / \mathrm{s}^{2}$ should allow a satisfactory braking process during an emergency stop in relation to the analyzed monorail set. However, the analysis of emergency braking under such different conditions as braking on a horizontal route and on a downward $30^{\circ}$ angle, leads to whether the algorithm should include information on the position/incline of the route. Then, based on the indications of the measuring system, e.g., an inclinometer installed on one of the monorail components, and the determined ranges of the route inclinations, the settings of the braking algorithm parameters could take different values.

Another area of testing should be related to the method of selecting the proportions of braking forces on the first and second stage of emergency braking to meet the total deceleration required by regulations. The selection of these parameters is very important and must be performed responsibly, ensuring the possibility of stopping the monorail in the most unfavorable variant of emergency braking, i.e., with the maximum permissible load to the monorail set during a downward travel with the greatest permissible angle of an inclination at the highest speed permissible for a given monorail. This process should be performed in such a way that the braking at the first stage during empty running of the monorail set on a horizontal route or running upward does not generate excessive dynamic overload. A braking system selected by this method, together with a properly adjusted control algorithm and perhaps a necessary system of additional safety components (i.e., safety belts, energy absorbers in the form of foam liners or vibration and energy dampers, used in links or suspension components of each cabin), should significantly improve the safety of the monorail passenger cabin, even at the higher speeds.

Author Contributions: Conceptualization, K.S. and K.H.; methodology, K.S.; software, K.S.; validation, K.H., J.Ś.; formal analysis, J.Ś., J.J.; investigation, K.S.; resources, K.S.; data curation, K.H.; writing—original draft preparation, K.H.; writing—review and editing, J.Ś.; visualization, K.S. and K.H., J.J.; supervision, J.Ś.; project administration, J.Ś.; funding acquisition, J.Ś. All authors have read and agreed to the published version of the manuscript.

Funding: The APC was funded by KOMAG Institute of Mining Technology and Silesian University of Technology-Faculty of Mechanical Engineering.

Institutional Review Board Statement: Not applicable.

Informed Consent Statement: Not applicable.

Data Availability Statement: Not applicable.

Acknowledgments: Part of the presented work was carried out under the European project INESI, "Increase efficiency and safety improvement in underground mining transportation routes". This project has received funding from the Research Fund for Coal and Steel under grant agreement No754169. Calculations were carried out at the Academic Computer Centre in Gdańsk, Poland.

Conflicts of Interest: The authors declare no conflict of interest.

\section{References}

1. Minister of Energy. Rozporządzenie Ministra Energii z dnia 23 listopada 2016 r. w sprawie szczegółowych wymagań dotyczących prowadzenia ruchu podziemnych zakładów górniczych [Regulation of the Minister of Energy "on detailed requirements for conducting underground mining plant operations", 23 November 2016]. J. Laws 2017, 1118. Available online: https: / / www.dziennikustaw.gov.pl/du/2017/1118 (accessed on 31 October 2021).

2. Ryabko, K.A.; Gutarevich, V.O. Substantiation of performance indicators of mine monorail locomotives. Min. Sci. Technol. 2021, 6, 136-143. [CrossRef]

3. Ignatkina, E.L.; Kostenko, A.V.; Tsarenko, S.N. Research of the Rate of Changing the Mine Suspended Monorail Brakeforce When Braking. IOP Conf. Ser. Earth Environ. Sci. 2021, 666, 022025. [CrossRef] 
4. Wu, G.; Chen, W.; Jia, S.; Tan, X.; Zheng, P.; Tian, H.; Rong, C. Deformation characteristics of a roadway in steeply inclined formations and its improved support. Int. J. Rock Mech. Min. Sci. 2020, 130, 104324. [CrossRef]

5. Li, G.; Ma, F.; Guo, J.; Zhao, H. Case Study of Roadway Deformation Failure Mechanisms: Field Investigation and Numerical Simulation. Energies 2021, 14, 1032. [CrossRef]

6. Pytlik, A.; Rotkegel, M.; Szot, Ł. Badanie wpływu prędkości kolejek podwieszonych na siły w wybranych elementach trasy. Przegląd Górniczy 2016, 11, 30-37.

7. Viktor, G.; Donetsk National Technical University; Evgenia, I. Study of the braking regime of rolling stock mining suspended monorail taking into account clearances in the coupling. Izv. Vyss. Uchebnykh Zaved. Gorn. Zhurnal 2020, 5, 108-115. (In Russian) [CrossRef]

8. Desai, R.; Guha, A.; Seshu, P. Multibody Biomechanical Modelling of Human Body Response to Direct and Cross Axis Vibration. Procedia Comput. Sci. 2018, 133, 494-501. [CrossRef]

9. Lynas, D.; Burgess-Limerick, R. Whole-body vibration associated with underground coal mining equipment in Australia. Appl. Ergon. 2020, 89, 103162. [CrossRef]

10. Issever, H.; Aksoy, C.; Sabuncu, H.; Karan, A. Vibration and Its Effects on the Body. Med. Princ. Pract. 2003, 12, 34-38. [CrossRef]

11. AlShabi, M.; Araydah, W.; ElShatarat, H.; Othman, M.; Younis, M.B.; Gadsden, S.A. Effect of Mechanical Vibrations on Human Body. World J. Mech. 2016, 06, 273-304. [CrossRef]

12. Kowalski, P.; Zając, J. Research on Simultaneous Impact of Hand-Arm and Whole-Body Vibration. Int. J. Occup. Saf. Ergon. 2012, 18, 59-66. [CrossRef]

13. INESI. INESI European Project: Increase Efficiency and Safety Improvement in Underground Mining Transportation Routes. RFCS, 2017-2020; Contract No. 754169, unpublished material.

14. Zasadni, W.; Kania, J.; Tokarczyk, J.; Rusinek, J.; Szymiczek, K. Możliwości zwiększenia prędkości jazdy kolejkami podwieszonymi $\mathrm{z}$ napedem własnym (Possibilities of increasing the speed of travel by self-propelled suspended monorails). In Proceedings of the Problemy Bezpieczeństwa i Ochrony Zdrowia w Polskim Górnictwie, Zawiercie, Poland, 14-15 April 2015; pp. 1-10.

15. Tokarczyk, J. Methodology for Identifying the Selected Mechanical Hazards in Auxiliary Transport of Underground Mines; Monograph Volume 52; Institute of Mining Technology KOMAG: Gliwice, Poland, 2018; ISBN 978-83-65593-08-5.

16. Dumitriu, M.; Gheți, M.A.; Cruceanu, I.C. Experimental Analysis of the Vertical Vibration of the Railway Bogie during Braking. Procedia Manuf. 2020, 46, 49-54. [CrossRef]

17. Gutarevych, V. Dynamic model of movement of mine suspended monorail. Transp. Probl. 2014, 9, 13-18.

18. Drozd, K.; Nieoczym, A. Dynamic Load of Suspension Chains Generated during the Movement of the Self-Powered Diesel Transportation System on a Suspended Monorail Track in the Mining Excavation; Monograph; Lublin University of Technology: Lublin, Poland, 2020; ISBN 978-83-7947-426-4.

19. Pytlik, A. Tests of steel arch and rock bolt support resistance to static and dynamic loading induced by suspended monorail transportation. Stud. Geotech. Mech. 2019, 41, 81-92. [CrossRef]

20. Horyl, P.; Šňupárek, R.; Maršálek, P.; Poruba, Z.; Pacześniowski, K. Parametric Studies of Total Load-Bearing Capacity of Steel Arch Supports. Acta Montan. Slovaca 2019, 24, 213-222.

21. Żuchowski, A. Analysis of the influence of the impact speed on the risk of injury of the driver and front passenger of a passenger car. Ekspolatacja Niezawodn. Maint. Reliab. 2016, 18, 436-444. [CrossRef]

22. Pytlik, A.; Tokarczyk, J.; Frąc, W.; Michalak, D. Explosive atmosphere ignition source identification during mining plant suspended monorail braking unit operation. Acta Montan. Slovaca 2021, 338-351. [CrossRef]

23. Ilyashov, M.; Diedich, I.; Nazimko, V. Prospective tendencies of coal mining risk management. Min. Miner. Deposits 2019, 13, 111-117. [CrossRef]

24. Cioca, I.L.; Moraru, R.I. Metoda szacowania ryzyka wybuchu i pożarów: Podejście ogólne, dostosowane do środowiska kopalni podziemnej [Explosion and/or fire risk assessment methodology: A common approach, structured for underground coalmine environments]. Arch. Min. Sci. 2012, 57, 53-60. [CrossRef]

25. Szewerda, K. Supporting development of suspended underground monorails using virtual prototyping techniques. IOP Conf. Ser. Mater. Sci. Eng. 2019, 545, 012018. [CrossRef]

26. Szewerda, K.; Tokarczyk, J.; Bożek, P.; Michalak, D.; Drwięga, A. Vibrations diagnostics and analysis in operator's and passenger cabins of a suspended monorail. Acta Montan. Slovaca 2020, 2, 150-158.

27. Herbuś, K.; Szewerda, K.; Świder, J. Virtual prototyping of the suspended monorail in the aspect of increasing the permissible travel speed in hard coal mines. Ekspolatacja Niezawodn. Maint. Reliab. 2020, 22, 610-619. [CrossRef]

28. Stankiewicz, K. Mechatronic systems developed at the ITG KOMAG. Min. Mach. 2020, 2, 58-68. [CrossRef]

29. Wojtyra, M.; Frączek, J. Metoda Układów Wieloczłonowych w Dynamice Mechanizmów; Oficyna Wydawnicza Politechniki Warszawskiej: Warsaw, Poland, 2007.

30. Verstraete, M.L.; Roccia, B.; Mook, D.T.; Preidikman, S. A co-simulation methodology to simulate the nonlinear aeroelastic behavior of a folding-wing concept in different flight configurations. Nonlinear Dyn. 2019, 98, 907-927. [CrossRef]

31. Spiryagin, M.; Persson, I.; Wu, Q.; Bosomworth, C.; Wolfs, P.; Cole, C. A co-simulation approach for heavy haul long distance locomotive-track simulation studies. Veh. Syst. Dyn. 2018, 57, 1363-1380. [CrossRef]

32. Jiang, Y.; Zhong, W.; Wu, P.; Zeng, J.; Zhang, Y.; Wang, S. Prediction of wheel wear of different types of articulated monorail based on co-simulation of MATLAB and UM software. Adv. Mech. Eng. 2019, 11, 1-13. [CrossRef] 
33. Yuan, R.; Fletcher, T.; Ahmedov, A.; Kalantzis, N.; Pezouvanis, A.; Dutta, N.; Watson, A.; Ebrahimi, K. Modelling and Cosimulation of hybrid vehicles: A thermal management perspective. Appl. Therm. Eng. 2020, 180, 115883. [CrossRef]

34. Szewerda, K.; Tokarczyk, J.; Wieczorek, A. Impact of Increased Travel Speed of a Transportation Set on the Dynamic Parameters of a Mine Suspended Monorail. Energies 2021, 14, 1528. [CrossRef] 